NBER WORKING PAPER SERIES

\title{
LOBBIES AND TECHNOLOGY DIFFUSION
}

\author{
Diego Comin \\ Bart Hobijn \\ Working Paper 11022 \\ http://www.nber.org/papers/w11022
NATIONAL BUREAU OF ECONOMIC RESEARCH
1050 Massachusetts Avenue
Cambridge, MA 02138
January 2005

We appreciate the superb research assistance of Erick Gong, Kristy Mayer and Bess Rabin. The paper has benefited from the comments of Daron Acemoglu, Philippe Aghion, Manuel Amador, Heski Bar-Isaac, Roland Benabou, Mark Doms, Catherine Haffer, Mike Kremer, David Laibson, John Leahy, Adam Przeworski, Paul Romer, Gilles Saint-Paul, Betsy Stevenson, Xavier Tafunell, Jim Robinson, Romain Wacziarg, Richard Zeckhauser and seminar participants at Harvard, San Francisco Fed, Stanford Business School, the NBER Summer Institute and NYU. Comin thanks financial assistance from the NSF and C.V. Starr Center for Applied Economics. The views expressed in this paper solely reflect those of the authors and not necessarily those of the Federal Reserve Bank of New York, nor those of the NBER, nor those of the Federal Reserve System as a whole.

(C) 2005 by Diego Comin and Bart Hobijn. All rights reserved. Short sections of text, not to exceed two paragraphs, may be quoted without explicit permission provided that full credit, including (C) notice, is given to the source. 
Lobbies and Technology Diffusion

Diego Comin and Bart Hobijn

NBER Working Paper No. 11022

January 2005, Revised January 2007

JEL No. N10,O30,O57

\begin{abstract}
Diego Comin
Department of Economics

New York University

269 Mercer Street, 725

New York, NY 10003

and NBER

diego.comin@nyu.edu

Bart Hobijn

Domestic Research Function

Federal Reserve Bank of New York

33 Liberty St.

New York, NY 10045

bart.hobijn@ny.frb.org
\end{abstract}

ABSTRACT

This paper explores whether lobbies slow down technology diffusion. To answer this question, we exploit the differential effect of various institutional attributes that should affect the costs of erecting barriers when the new technology has a technologically close predecessor but not otherwise. We implement this test in a unique dataset compiled by us that covers the diffusion of 20 technologies for 23 countries over the past two centuries. We find that each of the relevant institutional variables that affect the costs of erecting barriers has a significantly larger effect on the diffusion of technologies with a competing predecessor technology than when no such a technology exists. These effects are quantitatively important. Thus, we conclude that lobbies are an important barrier to technology adoption and to development. 
Cross-country differences in the degree of adoption of technologies are enormous (Comin, Hobijn and Rovito [2006]). Indeed, they are so large that have been pointed as the main factor causing the large cross-country differences in income per capita (Hsieh and Klenow [2003], for example). The fundamental question for growth theorists is what frictions generate these cross-country differences in technology adoption. In this paper we assess the role of one such friction on the adoption of new technologies. Namely, the political barriers erected as a result of the lobbying efforts of the producers of incumbent technologies.

Political barriers have long been believed to be an important deterrent to technology diffusion. Until now, however, this belief has only been founded in a few anecdotes. ${ }^{1}$ The lack of a systematic effort to prove this belief is the consequence of three difficulties. First, it is very hard to obtain direct measures of political barriers. Second, indirect measures of barriers are problematic because they typically are endogenous and either have independent effects on income per capita or are correlated with other variables that affect a country's development. Third, to explore the effects of lobbies on technology adoption, it is necessary to have a comprehensive data set on technology adoption, which, until recently, did not exist.

In this paper, we identify the effect of lobbies on technology diffusion by exploiting the different effect that certain institutions that affect the political cost of erecting barriers have on the diffusion of different technologies if lobbies matter but not otherwise. We present this identification strategy in Section 1 in the context of a simple model of lobbying and technology diffusion in the spirit of Parente and Prescott [2000], and Olson [1984]. The argument that motivates our identification strategy has two parts.

First, as shown both theoretically (Myerson [2003], Ferejohn [1986], Persson, Roland and Tabellini [2000]) and empirically (Kunicova and Rose-Ackerman [2002], Persson, Tabellini and Trebbi [2003] and Besley and Case [1995]), certain institutional attributes affect the political cost faced by the legislature when raising barriers to the diffusion of a new technology. In particular, the cost lobbies must incur to induce legislators to raise diffusion barriers are higher when legislators are not independent, the judicial system is effective, and the regime is democratic and non-military.

Second, the benefits old technology producers enjoy from raising barriers against the diffusion of a new technology depend on certain attributes of the new and old technologies. There are some new technologies that are so superior to the old technology that, even with political barriers, consumers prefer the new technology to the old one. In these cases, old technology producers find no benefit

\footnotetext{
${ }^{1}$ See Mokyr [1990] for examples.
} 
in lobbying for barriers. Thus, the new technology will diffuse quickly regardless of the costs of lobbying.

Other new technologies do, however, have close predecessor technologies because the productivity differential between old and new technologies is relatively small. In these cases, old technology producers may benefit from barriers to the new technology because in the presence of barriers consumers may prefer to use the old technology. The speed of diffusion of these new technologies depends, therefore, on the cost of erecting barriers. When it is costly to raise political barriers, lobbying is unsuccessful, barriers are not raised, and new technologies diffuse quickly. Conversely, when the cost of raising barriers is low, the legislative authority accepts the old technology's lobbying bribes and raises barriers that slow down the diffusion of the new technology.

It follows from these two premises that, if lobbies are a relevant concern, the speed of diffusion of technologies with technologically close predecessor technologies will be affected by the institutional attributes that affect the political cost of erecting barriers. These institutional attributes should have no effect, however, on the lobbying intensity against the diffusion of technologies with technologically distant predecessor technologies. This differential effect of institutions on the diffusion of different technologies is the basis for our identification strategy of the effect of lobbies on the speed of diffusion of technologies.

By inferring the effect of lobbies on technology diffusion in this way, we avoid the complexity of measuring the intensity of lobbying directly. ${ }^{2}$ In addition, we believe that this approach has three virtues that help it avoid most of the traditional identification problems. First, it focuses on the details of the mechanism by which lobbying affects technology diffusion, thus providing a stronger test of causality. Second, while it may be relatively easy to think of omitted correlates of the institutional variables that may have an independent effect on the diffusion of technologies, it is very complicated to find reasons why these correlates should have an effect on the group of technologies with a predecessor technology above and beyond the effect they have on the technologies without one. Section 3.4 discusses in detail the unlikeliness of biases due to the omission of relevant variables. Third, reverse causality is probably not an issue because it is hard to argue that the relatively micro technologies in our sample have an effect on the institutions of a country. Further, for the effect of technology on the institutional variables to invalidate our identification strategy,

\footnotetext{
${ }^{2}$ Rajan and Zingales [1998] use a similar strategy to identify the effect of capital markets development on economic development. One important methodological difference, though, is that while they have various measures of capital market development (the exogenous variable in their test), we do not have any direct measure of lobbying intensity.
} 
it must be relevant above and beyond our controls and must be triggered only by the diffusion of technologies with or without a technological predecessor. ${ }^{3}$

Section 2 documents the plausibility of our identification strategy with two historical case studies: railroads in China during the second half of the XIX ${ }^{\text {th }}$ century and telephones in Japan during the military regime from 1932-45. These case studies show first that, in countries with the institutional traits that the literature has shown reduce the cost of lobbying, parties with vested interests in close predecessor technologies engaged in intense lobbying activities resulting in the erection of barriers against the diffusion of new technologies. In countries without these institutional attributes or where the dominated technologies were not present, ${ }^{4}$ there are no records of lobbying activities or diffusion barriers. Second, our case studies illustrate how lobbying activities and political barriers slowed the diffusion of the targeted new technology relative to countries without similar lobbying activities. Further, after a change in the institutional traits that increase the cost of lobbying, we observe that lobbying disappears and that the diffusion of the new technologies with close predecessor technologies accelerates.

To go beyond the exploration of these case studies, we need an extensive data set on the diffusion of multiple technologies in various countries and, preferably, across many time periods. Fortunately, our Historical Cross-Country Technology Adoption (HCCTA) data set contains historical data on the adoption of 20 major technologies over the last 215 years for 23 of the world's leading industrial economies.

The results from our analysis suggest a significant negative effect of lobbying on technology diffusion. In Section 3, we find that each of our measures of the institutional attributes that affect the cost of lobbying, have a larger effect on the diffusion of technologies when there is a competing predecessor technology than in cases where there is no such an incumbent technology. Specifically, we find that in countries where the legislative authorities have more flexibility, the judicial system

\footnotetext{
${ }^{3}$ Of course, there may be other mechanisms by which lobbies affect the diffusion of new technologies different from the one we identify in this paper. For example, Acemoglu and Robinson [2000] and [2002] present models where the elite wants to block the diffusion of new technologies in order to preserve its political power. Similarly, unions may block the diffusion of labor saving innovations. (Our data set only contains one such innovation.) Since our identification strategy does not identify these mechanism, our estimates of the effect of lobbies on technology diffusion may in principle be downward biased.

${ }^{4}$ Canal transportation, the predecessor of railways, was unfeasible in countries without navigable rivers, a requirement for this technology. In those countries, then, there was no predecessor to railroads that had a small enough productivity differential to effectively lobby against them.
} 
is not effective, the regime is not very democratic or there is a military regime, new technologies that can substitute for a technological predecessor diffuse more slowly than technologies without such a predecessor technology. These results are robust. Further, they are not only significant, but also quantitatively important to understanding technology diffusion. In particular, the variance associated to the differential effect that institutional have on the diffusion of technologies with close predecessors represents over 50 percent of the total variance in technology adoption. ${ }^{5}$ Section 3.3 discusses in detail the unlikeliness that the estimated differential effect of the institutions that affect the cost of lobbying on the adoption of technologies with close predecessors result from a bias due to the omission of relevant variables. Therefore, we are inclined to conclude that the barriers raised by lobbies to deter the diffusion of new technologies are an important impediment to the diffusion of technologies.

Section 4 concludes by drawing the implications of this analysis for the empirical literature on the effects of institutions on development.

\section{The model}

We develop a model to understand under what circumstances lobbies make contributions, and when these contributions induce the legislative authority to erect barriers to slowdown the diffusion of new technologies. More specifically, the model highlights the importance of the interaction between attributes of the new and predecessor technologies and institutional traits that affect the costs of erecting barriers. ${ }^{6}$

\section{$1.1 \quad$ Setting}

Production- A representative firm produces output competitively. Up to two technologies are available for production, the old $(o)$ and the new $(n)$. When relevant, the output producer must decide which technology to use and how many units of the intermediate good that embody the technology

\footnotetext{
${ }^{5}$ Cross-country variation in technology adoption is approximately four time slarger than cross-country variation in income per capita (Comin and Hobijn [2004] and Comin, Hobijn and rovito [2006]).

${ }^{6}$ In the literature, there are various models of lobbying (Helpman and Grossman [1994], for example) and of endogenous political barriers to technology diffusion (Krusell and Rios-Rull [1996], Acemoglu and Robinson [2000 and 2002] and Acemoglu [2004]). Our identification strategy is based on the effects on diffusion of the interaction between the institutional traits of the country and the characteristics of the new and predecessor technologies. We opt for developing a new, simple model because these interactions have not been studied yet.
} 
to demand. More formally, output is given by

$$
Y=\max \left\{x_{o}^{\alpha}, d x_{n}^{\alpha}\right\}
$$

where $Y$ denotes the number of units of output produced, $d$ measures the technological progress embodied in the new technology relative to the old one, $x_{o}$ denotes the number of units of old technology intermediate good used, and $x_{n}$ denotes the number of units of new technology intermediate good used.

Each intermediate good is produced by one producer. Intermediate goods producers may incur two different types of costs. First, intermediate good producers may make transfers to the legislative authority in exchange for regulations that affect the marginal cost of producing the new intermediate good. ${ }^{7}$ Second, there is a marginal cost of producing intermediate goods, which has two components: one technological and one associated with the regulations. We make the following assumptions about the technological component of the marginal cost of producing intermediate goods: (i) initially, the marginal cost of production is equal to $\bar{a}$ for both old and new technologies; (ii) at some point (made precise below), the producer of the new technology intermediate good learns how to produce it efficiently, and the marginal cost of production for the new technology intermediate good becomes $\underline{\mathrm{a}}<\bar{a}$. All costs are indexed in terms of output, which is taken as the numeraire.

Institutions- The legislative authority $(L)$ determines the level of regulation $(\tau)$ the producer of new technology goods faces. There are two possible levels of regulation. ${ }^{8}$ Heavy regulation increases the marginal cost of producing new intermediate goods by $\bar{\tau}$, while no regulation (i.e. $\tau=0$ ) leaves the marginal cost of new intermediate goods unchanged.

The per period payoff of the legislative institution is the sum of three terms: a private value of being in power $(b)$, the contributions received $(C)$ and the costs of bending the political constraints imposed by other institutions $(S)$. The cost of passing regulations and $L$ 's discount rate depend on the actions taken by $L$ and on the institutional setting. It is costless for $L$ to set $\tau=0$ (i.e. $S(0)=0$ ). The cost of implementing $\bar{\tau}$ depends on $L$ 's independence. For an independent legislative authority, the cost is $\underline{\mathrm{s}}$, while for a less independent authority the cost of setting $\tau=\bar{\tau}$ is $\overline{\mathrm{s}}>\underline{\mathrm{s}}$.

\footnotetext{
${ }^{7}$ The model predictions would beunaffected if, instead of affecting the marginal cost of production, regulations affected the fixed cost of entry and this reduced the number of entrants associated with the new technology reducing the gains from variety associated from using it.

${ }^{8}$ The feasibility of only two tax rates may be completely general if, as in Acemoglu and Robinson [2000], there is an informal sector where producers can avoid the sales taxes but operate at lower productivity. $\bar{\tau}$ would then be the rate that makes the producer indifferent between operating in the two sectors.
} 
The decisions taken by the legislative authority also may affect his probability of remaining in power. We model this effect by making the discount rate a function of the regulations passed by the legislative authority and of the political regimes. In particular, the discount factor faced by the legislative authority that implements $\bar{\tau}$ in a democratic regime is $\beta(\bar{\tau})$, which is lower than the discount factor faced in all other cases and by all other entities in the economy. These are normalized to $1 .^{9}$ Below we elaborate more on this interpretation.

Timing- For simplicity, we consider a three-period economy. ${ }^{10}$ The old technology intermediate goods arrives in period 1. The old technology intermediate good is produced and the producer decides whether to make a conditional contribution to the legislative authority. $L$ decides whether to regulate the production of new technology intermediate goods for next period, (i.e. period 2) and lastly the random variable that determines whether the legislative authority remains in power or is replaced is realized.

At the beginning of period 2, the new technology arrives. Period 2 is symmetric to period 1 , with the only difference that now production and contributions can be undertaken by both the old and new technology producers. At the beginning of period 3, the technological component of the marginal cost of producing new technology intermediate goods declines to $\underline{\text { a. }}$ Otherwise, period 3 is identical to period 2 .

\subsection{Analysis}

Each period, the final output producer selects the technology that yields higher profits. Let $\pi(x)$ denote the profits of the output producer when using technology $x$. The relative profit ratio is then defined as

$$
\frac{\pi(n)}{\pi(o)}=\left[d\left(\frac{p_{o}}{p_{n}}\right)^{\alpha}\right]^{1 /(1-\alpha)} .
$$

Therefore, the final output producer uses the new technology if $d\left(\frac{p_{o}}{p_{n}}\right)^{\alpha}>1$. If instead, $d\left(\frac{p_{o}}{p_{n}}\right)^{\alpha}<1$, he uses the old technology. This decision rule introduces a Bertrand competition between the old and new intermediate good producers. The result of this competition is that the producer that supplies the intermediate goods charges a price equal to the minimum between the

\footnotetext{
${ }^{9}$ What will be important for our results is not that the discount factor may be lower in democracies than in dictatorships, but that the discount factor in democracies is more sensitive to the regulations passed by the legislative authority.

${ }^{10}$ None of the results derived in this model hinge on the finite time horizon.
} 
monopolist price and the marginal cost of production of the other producer (when he is around).

Empirically, political barriers do not stop new technologies from diffusing forever. We ensure this occurs in the model by assuming the following condition holds.

Condition 1: $d\left(\frac{\bar{a}}{\underline{a}+\bar{\tau}}\right)^{\alpha}>1$.

Condition 1 implies that, if both intermediate good producers charge their marginal cost of production in period 3, the final output producer uses the new technology even in the presence of heavy regulations on the production of new intermediate goods. Given this outcome at period 3, we can proceed solving for the political contributions each producer makes using backwards induction.

In period 3, intermediate good producers make no contribution to $L$ because the game finishes in that period. In addition, nobody will make contributions in period 2 because the outcome in the next period -that the new technology is demanded- occurs regardless of the contributions made.

The technology demanded at time 2 depends on the technological distance between the new and the old technology, $d$, and on whether, at period 1 , the old technology producer can induce $L$ to set $\tau=\bar{\tau}$ for period 2 .

In particular, if $d$ is sufficiently large, $\pi(n) / \pi(o)$ is larger than 1 even in the presence of barriers to the diffusion of the new technology. In this event, the new technology diffuses upon arrival. The following condition and Proposition 1 formalize this intuition.

Condition 2: $d\left(\frac{\bar{a}}{\bar{a}+\bar{\tau}}\right)^{\alpha} \geq 1$

Proposition 1 : Suppose Condition 1 and Condition 2 hold. Then new technologies diffuse immediately regardless of the institutional setting.

Alternatively, if Condition 2 does not hold (i.e. the new technology is not sufficiently superior to the old one), the final output producer may demand the old technology in the presence of diffusion barriers. This alone, however, is not sufficient to slow the diffusion of the new technology. The old technology lobby must also induce $L$, at $t=1$, to pass heavy regulations.

$L^{\prime}$ s payoff if he does not regulate is $3 b$. Regulating heavily yields $L$ a payoff of $b(1+2 \beta(\bar{\tau}))-$ $S(\bar{\tau})+C(\bar{\tau})$, where $C(\bar{\tau})$ is the conditional contribution made by the producer of the old technology intermediate good if $\tau=\bar{\tau}$. Therefore, $L$ sets $\tau=\bar{\tau}$ at time 1 if and only if the contribution covers the costs of passing the regulation and the expected loss from the losing office. That is, if

$$
C(\bar{\tau}) \geq 2 b(1-\beta(\bar{\tau}))+S(\bar{\tau})
$$

Is it feasible for the old technology producer to make such a contribution to $L$ ? The most he is 
willing to contribute to induce heavy regulations are the profits to be made at time 2 , since at time 3 the new technology diffuses.

If the old technology producer supplies intermediate goods at time 2 , he sets a price $p_{o 2}$ given by the following expression

$$
p_{o 2}=\min \left\{(\bar{a}+\bar{\tau}) d^{-1 / \alpha}, \bar{a} / \alpha\right\}
$$

The first term in $p_{o 2}$ is the price that makes the final output producer indifferent between using the new and the old technology. Whenever this constraint is not binding, the old technology producer will set the monopolistic price, $\bar{a} / \alpha$.

Given this optimal pricing rule, the profits accrued by the old technology producer in period 2 are

$$
\Pi_{o 2}=\left(p_{o 2}-\bar{a}\right)\left(\alpha / p_{o 2}\right)^{1 /(1-\alpha)}
$$

Condition 3 and Proposition 2 characterize the environment in which the new technology diffuses slowly.

Condition 3: $\Pi_{o 2}=\left(p_{o 2}-\bar{a}\right)\left(\alpha / p_{o 2}\right)^{1 /(1-\alpha)} \geq 2 b(1-\beta(\bar{\tau}))+S(\bar{\tau})$.

Proposition 2 : Suppose that Condition 2 does not hold and that Conditions 1 and 3 hold. Then, new technologies diffuse slowly (i.e. they diffuse in period 3).

Intuitively, since only the old technology producer is around at $t=1$, it can take advantage of this incumbency advantage to bribe $L$ to raise barriers to the adoption of the new technology when it arrives at period 2. Condition 3 ensures the feasibility of inducing $L$ to regulate. Since Condition 2 does not hold, the final output producer prefers the old technology when the new technology is regulated, and therefore the old technology producer keeps the market in period $2 .^{11}$

\subsection{Empirical Implications}

Next we use the model predictions to derive the exclusion restrictions that allows us to identify the importance of lobbying for technology diffusion. To this end, note that, for a given $\Pi_{o 2}$, Condition 3 holds if $\beta(\bar{\tau})$ is high and/or $S(\bar{\tau})$ is small. In other words, it holds when the country's institutions

\footnotetext{
${ }^{11}$ One interesting issue is whether it is possible for the new technology producer to compensate the old technology producer in exchange for not inducing $L$ to raise barriers against the diffusion of the new technology. This arrangement would increase social welfare, but would be hard to enforce. For a discussion of some of the difficulties in enforcing this kind of contract, see Comin and Hobijn [2005].
} 
make it easy to lobby $L$ for diffusion barriers because heavily regulating the new technology does not reduce $L$ 's probability of reelection and/or $L$ faces a small static cost of implementing the regulations. Conversely, when this is not the case, the institutional environment makes it costly to lobby $L$, and the new technology diffuses quickly.

Note, however, that having an institutional environment that makes it easy to lobby $L$ is a necessary, but not a sufficient condition for the new technology to diffuse slowly. In addition, the new technology must not be too technologically superior to the old one (i.e. Condition 2 must not hold). When Condition 2 holds, the new technology diffuses quickly regardless the institutional environment.

Table 1: Model Predictions I

\begin{tabular}{|l|l|l|}
\hline Technological attributes $\rightarrow$ & $\underline{\mathrm{d} \text { High }}$ & $\underline{\mathrm{d} \text { Low }}$ \\
\hline Institutional attributes $\downarrow$ & & \\
\hline Costly to Lobby Legislature & Fast Diffusion & Fast Diffusion \\
\hline Easy to Lobby Legislature & Fast Diffusion & Slow Diffusion \\
\hline
\end{tabular}

These implications, which are summarized in Table 1, yield the basic identification strategy. Namely, we identify the role of lobbying on technology diffusion by exploring the differential effect of the institutional attributes that affect the cost of lobbying on the speed of diffusion of technologies with technologically close predecessor technologies (low $d$ ) vs. technologies that are very superior to or have no predecessor technologies (high $d){ }^{12}$

There are sources of variation across technologies, other than differences in $d$, that also affect lobbying intensity. One relevant dimension is the elasticity of demand, $\alpha$, of the old technology. In Tirole [1988] and Aghion and Howitt [1998], the parameter $\alpha$ has been related to the size of the sunk costs, $F$, necessary for a producer (in this case, of the old technology) to begin operating. Intuitively, a higher $F$ reduces the number of old technology producers and, therefore, the elasticity of substitution between different intermediate goods associated to the old technology. Hence, a higher sunk cost, $F$, is equivalent to a smaller $\alpha{ }^{13}$

\footnotetext{
${ }^{12}$ Equivalently, we can explore the differential effect of the institutional attributes on the intensity of adoption of technologies with close predecessors vs. those without. This type of measures of technology diffusion are easier to obtain in the presence of heterogenity.

${ }^{13}$ Admittedly, this interpretation requires going beyond the simple model described above, in which only one firm produces the intermediate goods associated with a given technology. This interpretation is, however, a natural extension of the model presented above but, given the empirical character of this paper, we do not pursue it here.
} 
For simplicity, we restrict our exploration to the region of $p_{o 2}$ where the price charged by the old technology producer is not constrained by the presence of a new intermediate good producer. When $\alpha$ tends to 1 , the profits accrued by the old technology producer in period $2, \Pi_{o 2}$, tend to zero, and Condition 3 never holds because the old technology producer does not have sufficient rents to induce $L$ to raise barriers. For lower values of $\alpha$, whether Condition 3 holds depends on the institutions and on $d$. In particular, for intermediate values of $d$ and $F$, new technologies diffuse slowly only if the existing institutions make it easy to lobby the legislature. If institutions make it costly to lobby $L$, the new technology diffuses quickly for intermediate values of $d$ and $F$. When, instead, new technologies have a relative productivity, $d$, that is very large or when the production of old technology intermediate good involves very small sunk costs, $F$, new technologies diffuse quickly regardless of the country's institutional setting.

Table 2: Model Predictions II

\begin{tabular}{|l|l|l|}
\hline Technological attributes $\rightarrow$ & d High or F small & d Low and F Large \\
\hline Institutional attributes $\downarrow$ & & \\
\hline Costly to Lobby Legislature & Fast Diffusion & Fast Diffusion \\
\hline Easy to Lobby Legislature & Fast Diffusion & Slow Diffusion \\
\hline
\end{tabular}

Table 2 summarizes these conclusions, which are the basis for our second identification strategy. Namely, we identify the effect of lobbies on technology diffusion by estimating the differential effect of the institutions that affect the cost of lobbying on the speed of diffusion of technologies with and without high $d$ and small $F$.

Implementing these identification strategies requires (i) classifying technologies according to the technological distance and size of sunk costs involved in producing the predecessor technology and (ii) a list of institutions that affect the cost of lobbying the legislature. First, we will discuss the set of institutions that determine the cost of lobbying. The classification of technologies is discussed in the next section, where we present the data.

We consider four institutional traits that affect the costs of lobbying the legislature for barriers. First, the independence of legislators to pass regulations: Legislators with a high degree of independence do not have to respond to superior entities when passing regulations. As a result, they will face lower static costs $(S(\bar{\tau}))$ of erecting barriers. Second, the effectiveness of the judicial system: Accepting conditional contributions (i.e. bribes) is illegal in most countries, including all 
the countries in our data set. An effective judiciary that can detect, judge and sentence such violations makes it more costly for the legislature to accept bribes. As a result, $L^{\prime} s$ static cost of raising barriers $(S(\bar{\tau}))$ increases with the effectiveness of the judiciary.

Third, the degree of democracy: A growing body of research has observed that electoral pressure aligns officials' incentives with public interest. The theoretical strand of the literature has identified, three aspects of the electoral system that affect the degree of electoral competition officials face and should affect their incentives to extract political rents. These are (i) the ballot structure, (ii) the district magnitude and (iii) the electoral formula. With regard to (i), some electoral systems make incumbents individually accountable to the voters, while others elect politicians from party lists. A party-list system weakens individual incentives for good behavior because it creates freerider problems and makes chains of delegation more indirect (because they now go from voters to parties to politicians). As for (ii), fewer legislators elected in a typical electoral district (low district magnitude) may increase corruption because it raises barriers to entry (Myerson [1993]). A smaller number of parties (or ideological types) present themselves at the polls, and voters have less opportunity to oust corrupt politicians or parties (Ferejohn [1986], Persson, Roland and Tabellini [2000], Adsera, Boix and Payne [2003]). When it comes to (iii), the electoral formula may also shape rent extraction through the sensitivity of election outcomes to incumbent performance. Since incumbents may be more severely punished under plurality rule than under proportional representation (PR), the former may be more effective in deterring corruption (Persson and Tabellini [2000, ch. 9], Lijphart [1994, 1999] and Powell [2000]). On the empirical side, Kunicova and RoseAckerman [2002] find that, in a large cross-section of countries, closed-list systems are associated with more corruption. Persson, Tabellini and Trebbi [2003] also find that the higher electoral pressure that comes from each of the mechanisms described previously is associated with lower corruption. Finally, Besley and Case [1995] show that term limits in gubernatorial elections in US states are associated with higher taxes and higher government spending, compared with states without binding limits. It is then natural to think that the observed effectiveness of the electoral pressure in preventing officials from extracting political rents follows from the higher probability that, in more democratic societies, a legislator that is detected accepting conditional contributions is not reelected for the next term. Or, in terms of the parameters in our model, that $\beta(\bar{\tau})$ is lower in societies with higher democracy scores.

Fourth, by the same token, the horizon of the legislative authority in military regimes is more independent of the regulations passed than in civil regimes. Therefore, the final institutional trait 
that affects the dynamic cost of lobbying the legislature is whether the regime is military or civilian.

In the empirical section, we present various measures of these four institutional traits that, as we have argued, affect the cost of lobbying the legislature. Before going into the details of the data, we find it instructive to illustrate our identification strategy with a few historical examples.

\section{Case studies}

Although this paper aims for a general understanding of the effect of lobbies on technology diffusion, anecdotal evidence is still useful to illustrate the workings of our identification strategy. With this goal in mind, we explore two historical examples: the diffusion of railroads in China during the second half of the XIX ${ }^{\text {th }}$ century and the diffusion of telephones in Japan during the military regime from 1932-45.

\section{Railroads in China}

During the second half of the XIX ${ }^{t h}$ century, China was autocratically ruled by the imperial family. The degree of democracy as measured by the Polity index was 1 on a scale from 0 to 10, 10 being the most democratic.

At the time, navigable rivers were used to transport coal from the mines to the harbors. The introduction of railways could have improved the productivity of waterways (Kinder [1891]) but, as Fogel [1964] has shown, the productivity gain from railroads when canals are feasible, as in this case, is not overwhelming. These technological and institutional characteristics place railroads in China in the bottom right cell of Table 1. According to our model, the combination of the moderate gap between railways and canals and the lack of a democratic regime increase the probability of successful lobbying efforts from agents with vested interests in river transportation. As a result, we expect to observe a slow diffusion of railroads in China, a prediction that the historical evidence supports.

Several groups had vested interests in delaying the diffusion of railroads in China, including junk owners and officials who profited from the rice tribute being carried by boat through the canals. Brown and Wright [1981] and Kinder [1891] document some of the actions, including lobbying, that these interest groups undertook and the resulting barriers. The barriers include blowing up bridges (Kinder [1891]), not granting the permits to construct the railroads through good terrain or not granting the permits at all, and forcing the use of domestic materials and parts in the construction of the railroads, locomotives and cars. As we demonstrate below, these political actions slowed 
the diffusion of railroads in China, despite the fact that the terrain and geography were ideal for railroads (Kinder [1891]).

Our model predicts that in countries where there is no close substitute for the new technology, lobbying efforts (if they occur at all) should be unsuccessful. As a result, the new technology railroads, in this case- should diffuse quickly. We investigate next the empirical validity of these predictions in the cases of Spain, Portugal and Japan - all countries without navigable rivers.

The regimes that governed these countries for all or part of the second half of the XIX ${ }^{\text {th }}$ century were almost as autocratic as China's. ${ }^{14}$ Despite this institutional context, however, there were very few political barriers to the diffusion of railroads in Portugal, Japan and Spain. In particular, Mendoza [1989] documents the special prerogatives granted to railroad constructors before 1860, which included duty-free import of materials, tools and equipment, the purchase of land in favorable terms and fiscal tax breaks. In Japan, companies that built railroads also enjoyed a favorable treatment, including exemption from land taxes on the land used in connection with the railroad, access to loans and, for some companies, a government guarantee of a return on the capital subscribed until 1906 of 8 per cent (Ike [1955]). In addition, the government was directly engaged in the construction of some of the railways. By 1885, over 60 percent of the railroad system had been constructed by the government. This share was still over 25 percent by 1900. The government support to railroads resulted in a relatively fast diffusion of railroads in the Iberian Peninsula and in Japan.

Figure 1 displays the kilometers of railroads constructed between 1850 and $1900 .{ }^{15}$ The amount of railway in Spain, Portugal and Japan was much larger than in China, despite the fact that China's area is about 19 times Spain's, about one hundred times Portugal's and about twenty-five times Japan's. By the end of the XIX ${ }^{\text {th }}$ century China had 829 Km of railway, while Portugal had almost three times that, and Spain had 13 times that. Hence, the presence of a non-democratic regime is not sufficient to slow the diffusion of railroads. In addition, the new technology, railroads, must also have a close predecessor technology - in this case, canals.

The presence of institutions that make it easy to lobby is, however, a necessary condition for the slow diffusion of railroads. In countries without such institutions, lobbying efforts will be

\footnotetext{
${ }^{14}$ The average Polity score for democracy in Portugal between 1850 and 1899 was 1 as in China. In Spain, the regimes that governed during the 1850-75 period also had a low democracy score (1 most of the time), but Alfonso XII's regime brought important democratic reforms in 1875. This is reflected in the Polity score which reaches a value of 4 by 1879 and oscillates between 5 and 7 until the end of the century. In Japan, the average polity score between 1850 and 1857 was 0 , then it quickly increased to 5 in 1867 and remained there until 1900.

${ }^{15}$ This is the only measure available for these countries in this period.
} 


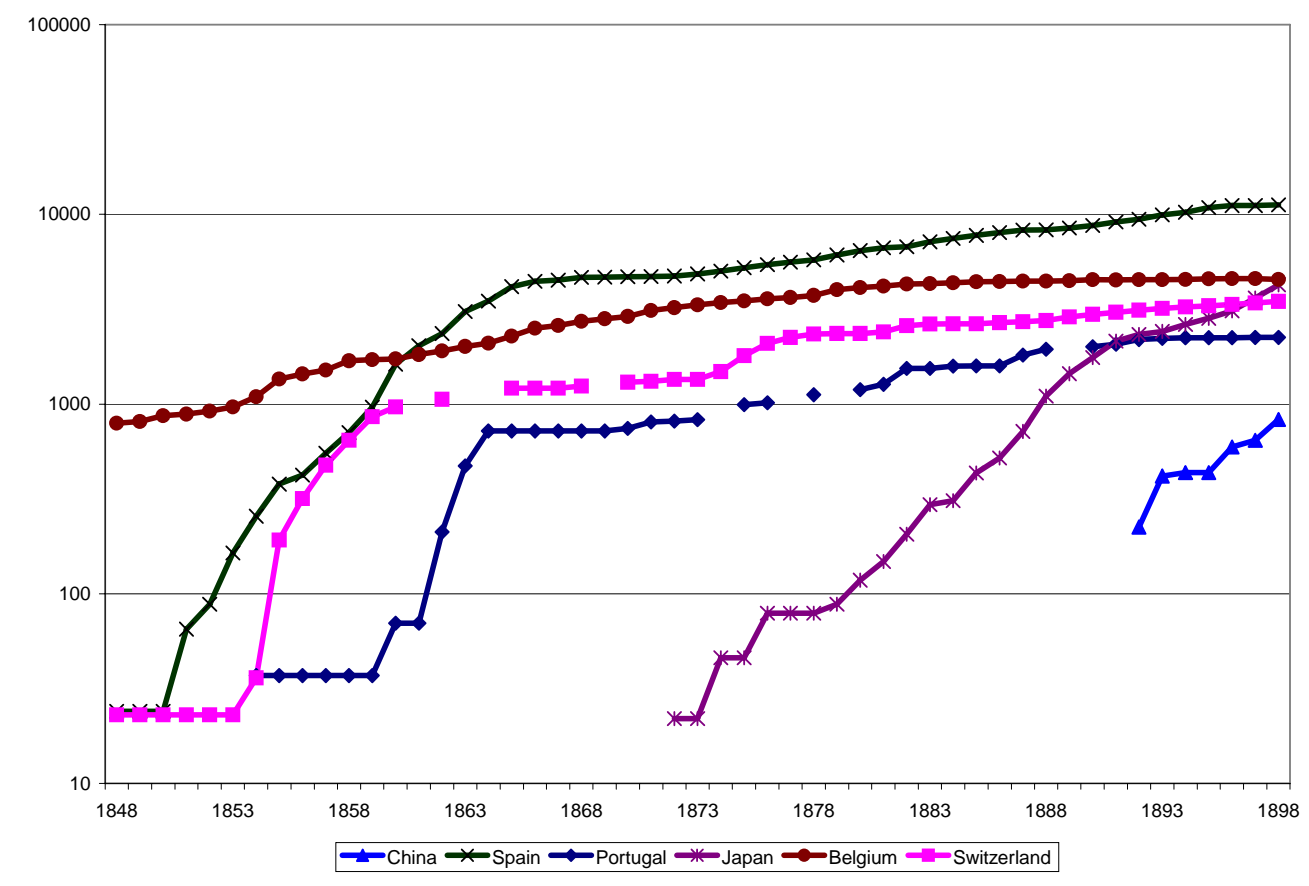

Figure 1: Kilometers of Railways

ineffective, and railroads shall diffuse quickly, regardless of the length of their waterways. Belgium and Switzerland illustrate this prediction.

By 1850, Belgium and Switzerland were two of the most democratic countries in Europe. ${ }^{16}$ Belgium and Switzerland differed significantly, however, in their use of waterways. Belgium was ahead of most European countries in the length of its canals. In contrast, Switzerland had few canals as its special geography prevented the use of waterways for transportation other than to cross lakes and to connect a few cities in the borders, such as Basel or Geneve, with the contiguous countries.

Despite the geographical constraints faced by Switzerland, railroad construction proceeded at a fast pace in both countries. ${ }^{17}$ Figure 1 illustrates this.

Our empirical strategy for identifying the role of lobbying on technology diffusion exploits the differential effects of institutions across technologies with and without close predecessors. In the case of railroads, that means that the differential effect of having a non-democratic regime on the

\footnotetext{
${ }^{16}$ The Polity score in Belgium was 7 from 1952 until the end of the century and in Switzerland it was 10.

${ }^{17}$ Spain between 1879 and 1900 is another example of a country without canals, with a good Polity score and with a relatively high level of diffusion of railroads.
} 
speed of diffusion of railroads in those countries with canals vs. those without canals is attributed to the lobbying efforts of agents with vested interests in the utilization of canals. That is, after controlling for other determinants of the speed of diffusion of new technologies, the difference in the gap between the length of railways in Belgium and China and the gap between the length of railways in Switzerland and Portugal is attributed to the barriers raised by lobbies to the diffusion of railroads in China. As is apparent from Figure 1, the inferred effect of lobbies on the diffusion of railroads is very significant. ${ }^{18}$

\section{Japan 1932-45}

Japan during the 1930s is another historical case that we use to illustrate our empirical strategy. From 1932 to 1945, Japan's government was effectively under military control. The only nonmilitary personnel who held government positions were the Emperor, who served as Chief of State, and a few civilians whose services were deemed necessary for successful conduct of government operations. The instauration of the military hegemony in 1932 coincides with the strengthening of regulations that made the adoption of modern technologies less profitable. One such regulation was the Major Industries Control Law, which allowed the government to form a list of "major industries" at their discretion and curtail the output of producers in those industries. Inclusion in the list usually resulted from the efforts of a coalition of established producers with more obsolete technology (Anchordoguy [2001]). This was the case, for example with cotton spinning and cement. ${ }^{19,20}$

\footnotetext{
${ }^{18}$ Of course, in our data set, the measures of the intensity of adoption of railroads are properly scaled.

${ }^{19}$ In December 1931, the cotton industry was included among the "Major Industries" under the control Law. This movement was in response to the demands of the older producers, who operated less efficient equipment. The application of the Major Industries Control Law lead to a substantial increase in curtailment rates. Further, since the latter part of 1935, recently installed spindles were subject to higher curtailment rates than older ones. In particular, the newly installed spindles were classified in two groups according to whether they had begun to operate between November 1st, 1932 and October 31st, 1935 or after the latter date. The additional curtailment rate imposed on the second group was much higher than that imposed on the first. In this way, curtailment rates protected inefficient producers and slowed the diffusion of new, more efficient spinning technologies.

${ }^{20}$ The Cement Federation (Rengokai) was formed in 1924, and its function was to control output by restricting members from producing at their full capacity. In 1932, the Rengokai's curtailment rate was raised to 55 percent when the industry came under the Major Industries Control Law. A few companies with more modern machinery, such as the Onada and the Oita Companies, protested against the uniform curtailment rates and withdrew from the cartel in order to expand their capacity. The cartel then appealed to the Government to enforce Article 2 of the Major Industries Control Law, and the Minister of Commerce and Industry agreed to this in December 1934. With this decision, the "outsiders" were compelled to accept the cartel's curtailment rates and to forego expanding their
} 
Curtailment rates tended to dissuade the adoption of new technologies for two reasons. First, the return to a new machine declines when a curtailment restriction forces its under-utilization. Second, curtailment rates for newer vintages were sometimes higher than for older machines.

In addition to curtailment rates, the military government also slowed the diffusion of new technologies by restricting FDI inflows. This policy was in part the result of lobbying efforts from incumbent Japanese producers whose profits were threatened by foreigners supplying newer technologies (Mason [1992]). As a result, FDI restrictions were more pervasive in sectors with a new technology and a competing predecessor technology, like communications.

Japan had been importing telegraph and telephone technology since the 1870's. Domestic producers initially just assembled products from imported parts, but they slowly started developing domestic technology to produce the parts. Domestic technology was initially inferior to imported technology, so, to accelerate the diffusion process, domestic producers merged with subsidiaries of foreign producers. This was the case with NEC and the overseas subsidiary of Western Electric, International Western Electric. When the gap between domestic and foreign technology decreased, domestic producers lobbied for limits on the share of telecommunication companies owned by foreigners and for the prohibition of FDI. These barriers brought improvements in newer telecommunication technologies, such as telephones, to a halt. In contrast, they had no effect on the efficiency of mature technologies, such as telegraphs, that had been already mastered by domestic producers. As a result, the substitution process of telegraphs by telephones was much slower in Japan than in other economies that did not suffer from the barriers raised by a military government in response to incumbents' lobbying efforts, such as France. This difference is depicted in Figures 2 and 3.

The log of telegrams per capita reached a maximum in France by 1920. At this point, the use of telegrams started a monotonic decline as they were replaced by telephones. In Japan, instead, the use of telegrams remained very high much longer and, in particular, did not decline at all during the 1930s.

The evolution of telephones per capita (Figure 3) is the opposite. Right before the instauration of the military regime in Japan in the early 30s, Japan caught up with France in the number of telephones per capita. With the new military regime, the gap in telephones per capita between France and Japan widened again, and it was not closed until 1960.

Our identification strategy attributes the difference in the adoption of telephones between France capacity. 


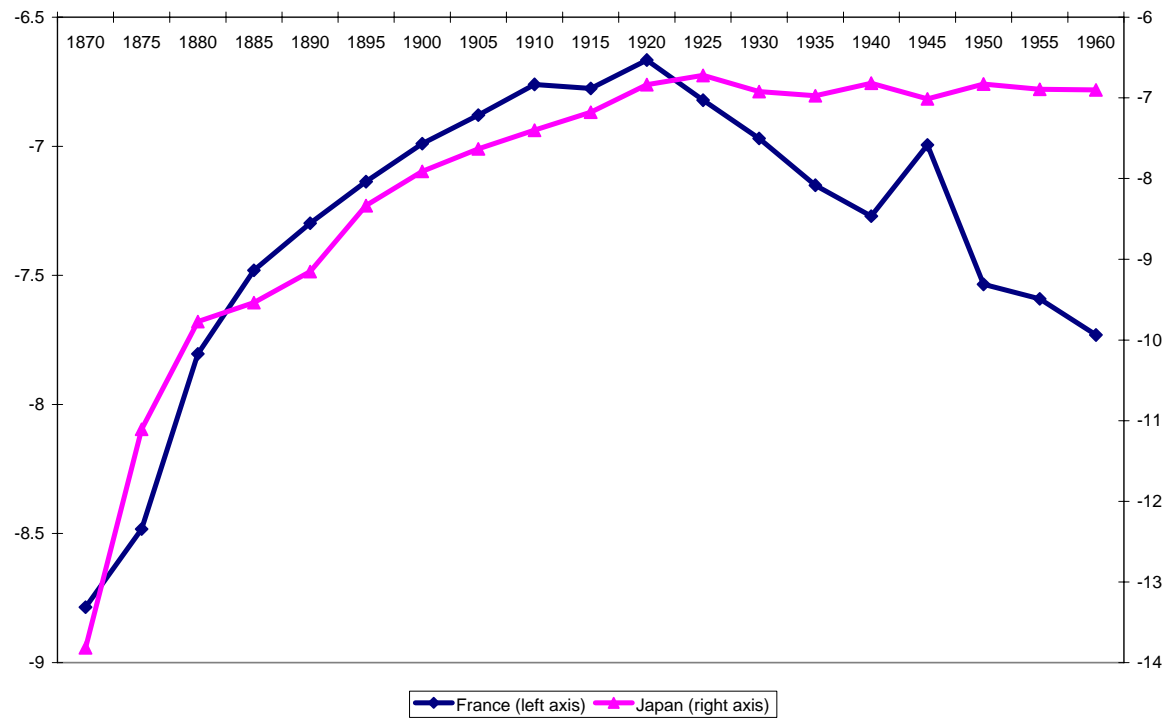

Figure 2: (Log of) Telegrams per capita

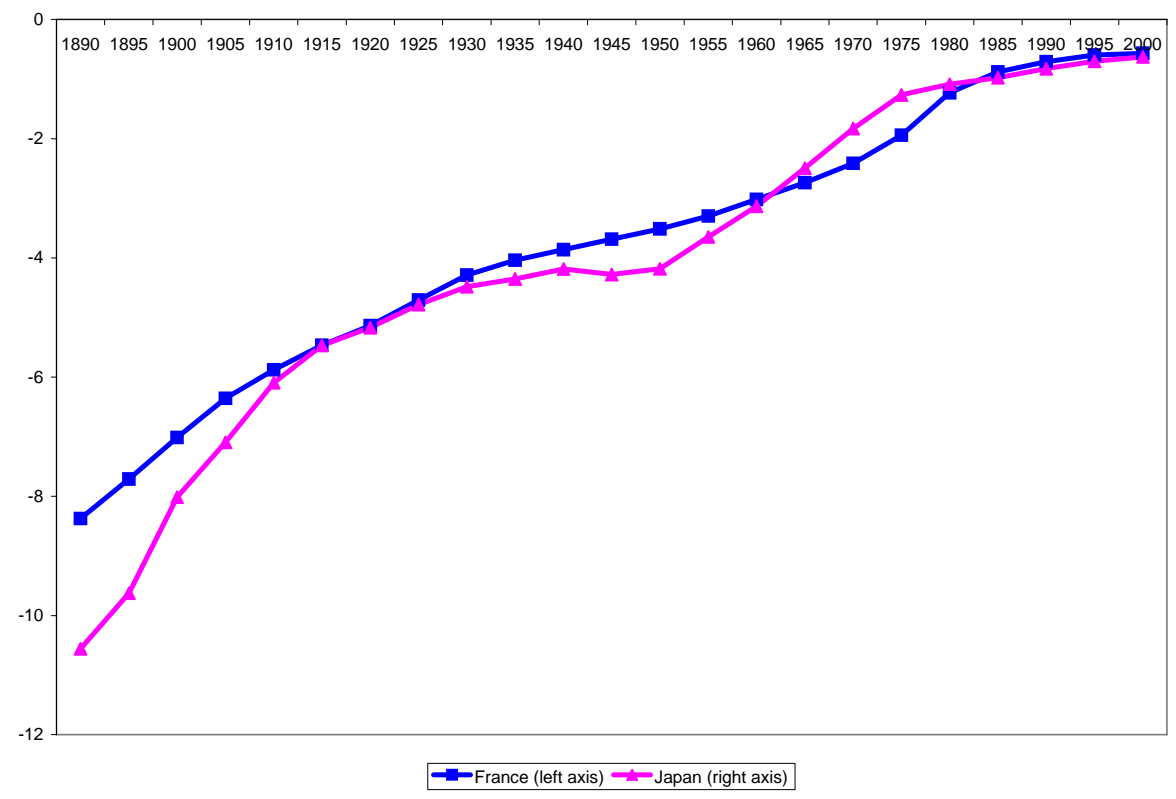

Figure 3: (Log of) Telephones per capita 
and Japan to the barriers raised by the military regime in response to the pressure of lobbies. ${ }^{21}$

After WWII the restrictions on technology importation gradually liberalized (Sekiguchi [1986] and Odagiri and Goto [1996]). As a result, technologies with close predecessors, such as telephones, cars and planes, began diffusing very quickly in Japan.

\section{Empirical exploration}

In this section we describe the data used in the empirical analysis. Then we present the econometric implementation of our identification strategy. Finally we present the estimates of the effect of lobbies on technology diffusion and argue in favor of the causal interpretation of the estimates.

\subsection{Data and classifications}

To test the predictions of the model we need to collect three types of variables. First we need to measure the diffusion of various technologies in different sectors and countries over time. Second, we need to classify technologies according to if they have a previous competing technology and, if they do, to the size of the sunk costs necessary to produce the predecessor technology. Finally, we need to collect information of the institutional setting in each country in our sample.

The information on technology diffusion comes from our Historical Cross-Country Technology Adoption (HCCTA) data set introduced in Comin and Hobijn [2004]. This data set contains historical data on the adoption of 20 major technologies over the last 215 years for 23 of the world's leading industrial economies.

Table 3 contains a list of the technologies used in this analysis and a list of the countries that

\footnotetext{
${ }^{21} \mathrm{~A}$ third sector in which we have found evidence of lobbying by producers of an old technology is transportation. In this case, since railways were partially owned by the government, it was the government itself the one that benefited from the barriers to the diffusion of cars, the new technology. The following quote documents the plans of the Ministry of Railways in 1930:

"In consequence of the very great increase in recent years in the use of omnibuses and motor trucks in Japan, the Ministry of Railways is investigating the question of co-ordinating and controlling omnibus and truck services, with a view to protecting railway services from excessive competition and encouraging motor services useful as feeders of the railways. The Ministry contemplates using, in its controlled services, omnibuses and trucks built in Japan, and Bill is now being prepared, for presentation to the next session of the Diet, empowering the Ministry to take over motor transport services." (Japan Political and Economic Reports 1926-1985)
} 
are included in our data set, which is basically the developed OECD economies. The technologies in our sample belong to seven sectors (i) textiles, (ii) steel, (iii) telecommunication, (iv) mass communication, (v) information technology, (vi) transportation (rail-, road-, and airways) and (vii) shipping.

We use five different types of measures for the level of technology adoption. The first, used for textiles and shipping, measures the fraction of capital equipment embodying a particular technology. Second, for technologies that are predominantly used in production, like trucks and robots, we measure capital output ratios. That is, we take the number of equipment units of a particular technology as a ratio of real GDP. For some production technologies we do not have capital stock data, but only data on output produced, like ton-kilometers (TKM) of freight transported using various transportation methods or tons of steel produced using various technologies. For those technologies we use production to real GDP ratios. Our final two measures are used for consumption (rather than production) technologies. Because of that, they normalize capital stocks and consumption measures by population rather than real GDP. Capital stocks per capita are used to measure, for example, passenger cars per capita and mobile phones per capita. Consumption per capita is used for mail, telegrams, as well as passenger transportation variables. ${ }^{22}$

Since we are interested in understanding the determinants of the speed of diffusion of new technologies along the transition path, for each technology we are going to use data only until a certain year, which is determined by one of two criteria. For some technologies, it may correspond to the point in time at which the distribution of the level of technologies across countries becomes constant. For other technologies that become dominated by an even newer technology, it corresponds to the year in which the level of technology starts declining. In either case, the truncation of the sample for a given technology is the same for all countries.

We classify technologies according to two criteria. First we classify them according to whether or not they have a previous competing technology. There are two senses in which a new technology may be very superior to the existing technologies, and thus not have a previous competing technology. In a vertical sense, a new technology does not have a competing technology if it can conduct the same tasks as the previous technology, but much more efficiently. In a horizontal sense, a new technology does not have a previous competing technology if it can perform important tasks that were previously unfeasible.

\footnotetext{
${ }^{22}$ Table A2 shows the robustness of our findings to scaling all technology adoption measures by population rather than scaling some by population and others by GDP.
} 
Measuring these relative productivities is not trivial for a variety of reasons. First, the relative productivity of the new technology will surely vary over time. This is consistent with condition 1 in our model by which, eventually, new technologies always diffuse. To determine whether the relative productivity is so large that Condition 2 holds, however, we focus on the relative productivities over a relatively short period (always less than 30 years) after the new technology is first invented. Second, the relative productivity of the new technology may vary across countries and/or across activities (typing vs. computing for PC's) or across routes (for transportation technologies). Of course, it is virtually impossible to take all these dimensions into account. As a result, our estimates of the relative productivity will be noisy. However, since there is a large dispersion in the observed relative productivities, we believe that our classification of technologies is relatively accurate. To gain more confidence in the conclusions, we check the robustness of the results to variations in the few cases where the classification is not so clear. All our results are robust to eliminating one by one the technologies. Hence, the results are not driven by any single technology.

To undertake our classification we have searched the historical literature for studies that compare new and old technologies along the relevant dimensions. Appendix 1 discusses the relative productivities estimates for the various technologies and the references for these studies. Table 4 summarizes these estimates. The second column of this table lists, for each technology, the predecessor technology or technologies. The third column contains estimates of the vertical distance between the technology and its predecessor/s. These may be the relative speed in conducting a representative task (e.g. travelling from city A to city B) or, for some technologies, the relative variable cost of conducting a representative task (e.g. cost of transmitting a one page letter from city A to city B). Finally, column 4 describes relevant activities that become feasible with the new technology.

The following briefly summarizes the productivity differential between the technologies we analyze and their predecessors. A more thorough description is given in Appendix 1.

Six of the technologies in our sample - Bessemer, electric arc, telegraphs, railroads, PCs and robots - were significantly more productive than their predecessor technologies. Bessemer developed a system to produce steel in industrial quantities. Prior to Bessemer, steel was produced by the crucible method, which took 14-15 days to produce 50 pounds of steel. The Bessemer method produced five tons of steel in half an hour. This supposes an increase in output per hour of about half a million. Electric arc furnaces made possible for the first time the production of stainless steel. The telegraph rendered curriers obsolete. It reduced the time to transmit one page of written 
text from Chicago to New York from 10 days to five minutes, a three-thousand-fold reduction, an it reduced the cost by a factor of 100. Prior to the railroads, it took between two to four days to travel the 90 miles that separate New York from Philadelphia, which gave an average speed of just above two miles per hour. Within a few years of the introduction of railroads, the average speed of railways was ten times higher than that. Personal computers increased enormously our computing capacity at a rate that doubled every 18 months after their invention. Industrial robots introduced a great deal of flexibility into the manufacturing of certain goods, leading to improvements in productivity by a factor of up to four.

For the rest of technologies in our sample, the technological distance with their predecessors, though still significant, was relatively small. As late as 1914, ring spindles were not faster than mules spindles. Blast oxygen furnaces were the biggest innovation in steel production since Bessemer, but they only improved productivity by a factor of 2.5. Telephones reduced the average time spent dispatching trains, dispatching news and transmitting one page of text by a factor of less than three. The estimated increase in productivity associated with replacing phones with mobile phones is only about one third. The introduction of freight trains increased the speed of cargo transportation by a factor of 2 or 3 with respect to canal transportation. Hence whenever canals were available, cargo trains did not constitute a radical improvement in transportation. However, in countries without navigable rivers their impact was enormous. Cars and trucks did not increase the speed of transportation over trains, although trucks might have reduced the cost of shipping cargo over short distances by 20 to 30 percent. By 1940, planes had improved traveling speeds by a factor of no more than four or five. As late as 1893, steam ships were just 20 percent faster than state of the art sailing ships.

Radios and TVs deserve a separate analysis. Experiments have shown that advertisement recall rates are not higher for radios or TVs than for newspapers. However, the two brought image and sound to the media, and these are important horizontal improvements over newspapers and magazines. In our analysis, we will experiment by classifying radios and TVs as both revolutionary and non-revolutionary technologies.

Based on this discussion, the list of technologies that were significantly more productive than previous technologies is Bessemer steel, electric arc furnace steel, telegrams, newspapers, personal computers, industrial robots, passenger transportation by railroads and, for countries without navigable rivers, cargo transportation by railroads. The group of technologies with a technologically close predecessor includes ring spindles, steel produced with blast oxygen and with open hearth 
furnaces, telephones, mobile phones, radios, TVs, cars, trucks, passengers and cargo transported by airplane and in steam and motor shipping.

The second scheme by which we classify technologies recognizes the difficulty of lobbying when the production of the old technology is dispersed. Specifically, we consider that a technology has a competing concentrated predecessor if (i) the production of the previous technology requires large sunk costs and (ii) the productivity gap between new and old technology is small.

Our research, described in Appendix 2, shows large sunk costs were required to begin producing Bessemer and open hearth steel; to install telegraphs and telephone lines; to construct canals, railroads and trains; and to begin producing cars, trucks and sail ships. Note that, based on our first classification, the productivity gap between these and the subsequent technologies was not very large. Therefore, the technologies with competing and concentrated predecessor technologies are open hearth and blast oxygen steel, telephones, mobile phones, trucks, cars, planes, steam and motor ships and cargo transportation by train wherever canals were available. The predecessors to all the other technologies in our sample either lag very much behind the productivity of the new technology or their production required much smaller sunk costs than the technologies just listed. In particular, the production of mule spindles, newspapers and radios did not require large sunk costs. Therefore, ring spindles, radios and TVs which were previously classified as having a competing predecessor are now classified as not having a concentrated competing predecessor. The rest of technologies in the sample did not have a competing predecessor in the first classification, and therefore cannot have a concentrated competing predecessor.

Note that, by construction, the two classifications of technologies are correlated. Since the correlation between these classifications is less than perfect (about 75 percent), however, this duality provides us with a second identification scheme to estimate the effect of lobbies on the diffusion of new technologies. In particular, it allows us to check the robustness of the results to the classification of TVs and radios, which, given the horizontal nature of their technological improvements, it is hard to determine whether they had or not a technologically close predecessor. In addition to using these two classification schemes, we will conduct several robustness checks to make sure our results are not driven by the classification of any single technology.

Finally, we use the following measures of legislative independence, effectiveness of the judiciary, degree of democracy and degree of military regime.

Legislative independence is measured by the Cross-National Time-Series Data Archive (also known as the Banks dataset) by assigning one of four values to a country: (0) indicates that 
no legislature exists. (1) is assigned on three possible bases: first, legislative activity may be essentially of a "rubber stamp" character; second, domestic turmoil may make the implementation of legislation impossible; third, the effective executive may prevent the legislature from meeting, or otherwise substantially impede the exercise of its functions. (2) corresponds to a situation in which the executives power substantially outweighs, but does not completely dominate, that of the legislature. Finally, (3) is assigned when a significant governmental autonomy is possessed by the legislature, including, typically, substantial authority with regard to taxation and disbursement and the power to override executive vetoes of legislation. Given the countries and period covered in our data set, most of the variation in this variable comes from country-periods that are classified as (2) rather than (3), which is the mode.

We follow La Porta et al. [1998] and measure the effectiveness of the judiciary with the crosscountry measure compiled by the Business International Corporation. We take the average of the measures between 1980 and 1983, which is scaled to between zero and ten, with lower scores meaning lower levels of judicial efficiency.

The democracy of a regime comes from Polity IV. This variable measures the general openness of political institutions. Specifically, it sums measures of the competitiveness of political participation, the openness and competitiveness of executive recruitment and the constraints on the chief executive. The result is a variable between zero and ten with higher values indicating more democratic regimes.

Finally, we classify regimes between those that are military and those that are not military using the Banks data set. A military regime is one that is explicitly or implicitly controlled by a military component of the nation's population.

For all the variables used in our analysis, we compute five-year averages and use non-overlapping data in our regressions. Taking these five year averages increases the signal-to-noise ratio of our variables and, a priori, does not reduce much of the relevant variation in the data since both technology diffusion and institutional change are relatively low frequency phenomena. Table 6 contains the descriptive statistics of the variables used in the econometric analysis.

Next we implement our identification strategy, present our estimates and discuss their interpretation. 


\subsection{Results}

The basic regression we run has the following form:

$$
y_{i c t}=\alpha_{0}+\alpha D_{i t}+\beta_{1} X_{c t}+\beta_{2} R_{c t}+\beta_{3} I_{i} * R_{c t}+\epsilon_{i c t} .
$$

$y_{i c t}$ denote our measure of the adoption of technology $i$ in country $c$ at time $t . \alpha_{0}$ is a constant. As explained above, we measure different technologies using different units. Further, as shown in Comin et al. (2006), technologies follow different diffusion paths. To control for these differences in diffusion across technologies we always include in our regressions a full set of time and technology specific fixed effects denoted by $D_{i t}$. This implies that, effectively, our dependent variable is the deviation in the adoption level of each technology $i$ in country $c$ at time $t$ from the average adoption level in the technology and period across countries. $X_{c t}$ is a set of controls that have been highlighted in the diffusion literature as being important for purely neoclassical reasons. This vector includes the level of income per capita, various measures of educational enrollment ${ }^{23}$ and the adoption of complementary technologies measured by the production of electricity over real GDP.

$R_{c t}$ represents the set of institutional variables that affect the cost of lobbying. These are legislative flexibility, effectiveness of the judiciary, the democracy index and the military regime dummy.

The fourth set of regressors in (2), $I_{i} * R_{c t}$ interacts the institutional variables $\left(R_{c t}\right)$ with either a dummy variable for the technologies that have a competing predecessor technology or a dummy for the technologies with concentrated and competing predecessors $\left(I_{i}\right) . \beta_{3}$ is the critical vector of coefficients for the identification of the role of lobbying activity on technology diffusion. Specifically, if lobbies slow down the diffusion of new technologies, we should observe that the effect of institutions that increase the cost of lobbying on technology diffusion is larger for technologies with a competing incumbent technology than for technologies without one. This implies that $\beta_{3}$ should be positive for institutional variables that increase the cost of lobbying - such as the degree of democracy or the effectiveness of the judiciary - and negative for variables that decrease the cost of lobbying such as the independence of the legislature and the military regime dummy. Finally, $\epsilon_{i c t}$ is an error term.

Table 7 reports the first set of coefficient estimates from regression (2). Each column corresponds to a different regression. In this table we only explore the interactions with the competing

${ }^{23}$ The enrollment rates in primary and secondary schooling before 1970 are computed by us, for the years after 1970 it is computed by the World Bank. 


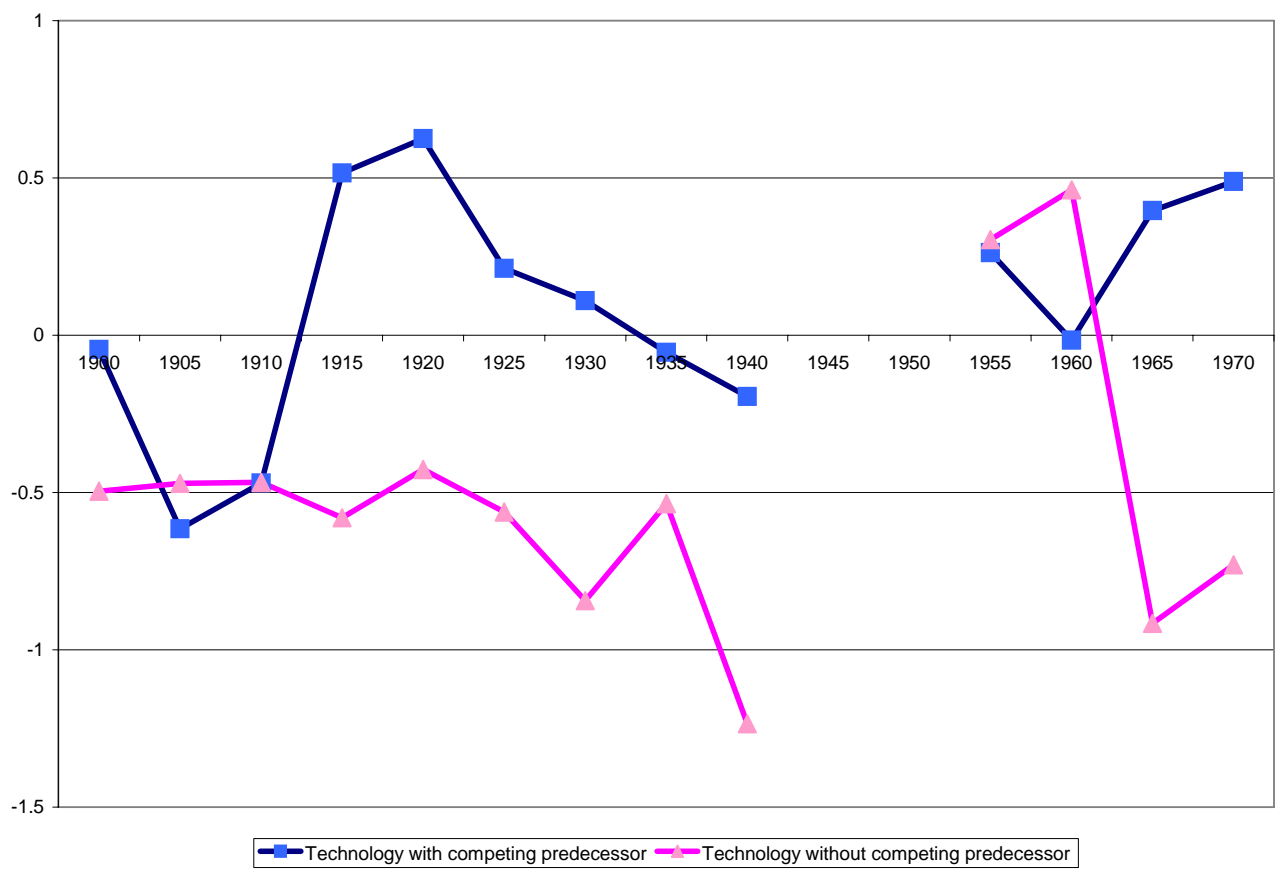

Figure 4: Increase in adoption from higher democracy score by technology group

predecessor technology dummy, leaving for Table 8 the regressions based on the interactions with the concentrated and competing predecessor technology dummy. Column 1 corresponds to a basic regression with only the vector $X_{c t}$ as a regressor. There we can observe that income per capita, the primary enrollment and the intensity of electricity production are positively associated with the level of technology diffusion. The positive coefficient for enrollment, however, only holds for enrollment before 1970 .

Rather than including at once the four institutional variables in $R_{c t}$ and the associated interactions with the competing predecessor technology dummy, $I_{i} * R_{c t}$, we find it instructive to introduce them successively. ${ }^{24}$ Since the comparative statics that motivate the identification strategy are valid "keeping everything else constant", we delay the interpretation of the results until the column that includes all four institutional traits.

Column 2 starts with democracy. Democracy is associated with a lower diffusion of new technologies. This observation is orthogonal to our test. The relevant finding for our test is that

\footnotetext{
${ }^{24}$ Of course, there may be some arbitrariness in the order in which the variables are added to the regression. This is not a relevant concern here because the succesive inclusion of institutional controls is used only for illustrative purposes.
} 
democracy has a significantly larger (i.e. more positive) effect on the diffusion of those technologies with a close predecessor technology.

We illustrate this finding graphically in Figure 4. This figure shows a measure of the effect of democracy in the adoption of technologies with (blue line) and without (pink line) competing predecessor technologies for each five-year period. In particular, we take column 2' estimates and add the predicted effects of democracy (both the overall and the interacted with the technology classification) to the error term. Let's call this variable the modified error. Then we classify countries according to wether they have a democracy score of more than 7 or not in each period. Finally, we compute the average modified error for technologies with and without competing predecessors in countries with high and low democracy scores and for each period. Figure 4 plots the difference in the modified average error between observations with high and low democracy scores for the adoption of technologies with and without competing predecessors.

Figure 4 shows that in all but four five-year periods, a higher democracy score is associated with a more intensive level of adoption of technologies with competing predecessors than of technologies without a competing predecessor (i.e. the blue line is above the pink one). In three of the four periods where this is not the case, the effect of democracy is very similar across technology groups. The larger effect of democracy on the adoption of technologies without competing predecessor in 1960 is entirely driven by mail in Greece. The cross-country variance of technology adoption after removing the fixed effects is approximately 0.9 . The average difference in the effect of democracy between technologies with and without competing predecessors over the sample period plotted in Figure 4 is 0.59 . This suggest a quantitative important role of the differential effect of democracy in explaining the cross-country variation in technology adoption. Below, we elaborate more formally on this conclusion and make it extensive to the other institutional variables.

In column 3 we inspect the conditional effect of the military dummy and its interaction with the predecessor technology dummy on technology diffusion. Having a military regime does not significantly affect the diffusion of new technologies in general. However, it significantly slows down the diffusion of new technologies that have a competing predecessor technology.

In column 4 we add the independence of the legislature to the set of institutional controls $R_{c t}$. The degree of flexibility enjoyed by the legislature does not have a significant effect on technology diffusion in general. It, does, however, slow the diffusion of new technologies with a competing predecessor technology.

Column 5 also adds the judicial effectiveness to $R_{c t}$. This variable does not have a significant effect 
on the diffusion of new technologies in general. However, judiciary effectiveness has a significantly larger effect on the diffusion of technologies with a competing predecessor technology than on the diffusion of technologies without one. The other proxy for the static political costs to the legislative authority of raising diffusion barriers is the legislative flexibility variable. Consistent with the theory, we also observe that a high degree of legislative flexibility reduces the speed of diffusion of the technologies with a competing predecessor by more than that of the technologies that do not have a competing predecessor.

Similarly, column 5 shows that the regime variables also have a differential effect on the diffusion of technologies with competing predecessor consistent with the relevance of lobbying in slowing the speed of diffusion of technologies. Specifically, being in a military regime slows the diffusion of technologies with a competing predecessor technology by more than the diffusion of technologies without a competing predecessor technology. Finally, a higher degree of democracy is associated with faster diffusion for technologies with a competing predecessor technology than for technologies without one.

Table 8 reports the estimates for regression (2) when we classify technologies not only according to the technological gap with the predecessor, but also according to whether the production of the predecessor technology was concentrated. The differential effects of institutions in the diffusion of technologies with and without concentrated predecessors are very similar to the effect across technologies with and without competing predecessors. We find that democracy and judicial effectiveness have a significantly larger effect on the diffusion of technologies with concentrated predecessors. We also observe that legislative effectiveness and military regime have a negative and significant differential effect on the diffusion of technologies with a concentrated predecessor.

Our model emphasizes the importance of this dynamic component to policy making. In particular, current institutions affect the political barriers next period. Hence, in our regressions, the exogenous variables should reflect the lagged, rather than contemporaneous, institutions. In addition to being closer to the model, this variation should mitigate the possibility that our estimates are driven by reverse causality. In the first two columns of Table 9, we re-run the basic regression for both classifications of technologies, replacing the institutional variables with their five-year lag. Interestingly, all the results hold, even a fortiori.

The estimated effect of lobbies on technology diffusion, in addition to being statistically significant, is quantitatively relevant. The variance of the diffusion level of the technologies with a predecessor after removing the effect of the technology-time dummies is 0.9. The dispersion induced 
by the estimated effect of the differential effect of institutional/policy variables on the diffusion of technologies with a predecessor is 0.46 . This means that the estimated effect of lobbies on technology diffusion represents 50 percent of the observed variation in technology diffusion.

The validity of the standard errors used to determine the statistical significance of our estimates hinges on the assumptions made about $\epsilon_{i c t}$. Next we show that our results are qualitatively and quantitatively robust to various assumptions about the error terms. We illustrate this using the specification in the first two columns of Table 9. The conclusions we reach for this particular specification are representative of all the specifications run in our analysis. Recall that in these columns we report the estimates of regression (2) using a five year lag in the institutional variables. The odd columns in Table 9 report the the estimates of the interactions of the institutional variables with the competing predecessor technology dummy. The even columns do the same for the interactions of the institutional variables with the concentrated and competing predecessor technology dummy. We consider three alternatives to our baseline robust standard errors. Columns 3 and 4 cluster the error terms at the country level. Columns 5 and 6 permit the correlation of the error term within each of the technology-country clusters. Finally, columns 7 and 8 allow for serially correlated errors. Specifically, we allow for heteroskedastic errors with a different AR(1) process for the errors terms in each technology-country cluster.

Comparing columns 1 and 2 with columns 3 through 6 we observe that clustering the errors does not affect the significance of the interactions of the technology classification dummies with democracy, the military regime dummy and legislative flexibility. Clustering, however, makes insignificant the differential effect of lagged judicial effectiveness on technologies with close predecessors and/or concentrated predecessor technologies. Whether we cluster the error terms in country groups or technology-country groups does not make any difference.

In columns 7 and 8 we use a feasible generalized least squares (FGLS) estimator to allow for serial correlation and clustering in the error term. The point estimates obtained with this estimator are quite similar to the point estimates obtained with our fixed effect estimator. The signs of the estimated differential effects of the institutional variables on technologies with concentrated and/or competing predecessor technologies are unchanged, though the absolute value of these estimates decline a little. The FGLS estimator, however, is more precise, and the t-statistics of the differential effect of the institutional traits on the technologies with concentrated and/or close competing predecessor technologies are even higher than those with the other estimators. The results that we present in the rest of the paper are also very robust to these variations in the specification for the 
error term.

\subsection{Interpretation and robustness}

We believe that we can interpret the results presented so far as evidence of a causal negative effect of lobbies on technology diffusion. This interpretation of the differential correlation between institutions and diffusion for the technologies with competing and concentrated, competing predecessor is motivated by how unlikely it is to find omitted variables that drive the correlation. These variables should be correlated to the institutional controls and have a larger effect on the diffusion of technologies with a close predecessor than on technologies without one.

Good governments, climate, unmeasured factors, high TFP and all the usual suspects that normally explain why we find positive correlation between institutions and development levels fail to explain why the effect of the relevant institutional variables is stronger for technologies with a competing or concentrated, competing predecessor. Next, we discuss various observations that make this failure to find a relevant omitted variable more general.

Sector-specific omissions: In the sectors in our sample there is an even representation of technologies with and without competing predecessors. The same is true for technologies with and without concentrated, competing predecessor technologies. Thus, the omission of sector-specific variables that symmetrically affect the technologies in the sector does not rationalize our estimates.

To show this formally, we include in our baseline regression the interaction between each of the four institutional variables and each of the six sectors. In Table 10, we focus on the classification of technologies based on the presence of a competing predecessor, while Table 11 reports the estimates of the differential effects of institutions on technologies with concentrated, competing predecessors. For comparison purposes, column 1 in Tables 10 and 11 are taken from columns 1 and 2 in Table 9. As anticipated, column 2 of Tables 10 and 11 show that the inclusion of sector-specific effects of the institutional traits that affect the cost of lobbying does not reduce the size and significance of the differential effects of these traits on the diffusion of technologies with competing (Table 10) and with concentrated, competing predecessors (Table 11).

An example can help us illustrate how much this restricts the set of omitted variables that could induce our estimates. One could think that the inverse of the productivity distance between new and old technologies is a proxy for the capital intensity of the technology- the omitted variable.

Naturally, the protection of property rights is more relevant for the diffusion of more capital intensive technologies, since capital is easier to expropriate than labor. Then, good institutions that protect 
better property rights should have a stronger effect on the diffusion of technologies with a close predecessor technology. Thus, the omission of the interaction between capital intensity classification and the institutional variables would bias the estimates of the interaction we introduce in regression (2).

This argument, however, rests on the premise that there is a negative correlation between the capital intensity of a technology and its productivity advantage with respect to the predecessor technology. This premise does not hold in our sample of technologies because the capital intensity of our technologies depends mostly on the sector the technology belongs to (i.e. transportation, steel, telecommunications, and IT are capital intensive while textiles and mass communications are not), and in most of the sectors we have an even distribution of technologies between those that have close predecessors and those that do not. Therefore, not controlling for the capital intensity of technologies or for any other attribute that is relatively homogeneous within the sector will not result in a bias of our estimates. ${ }^{25}$

Omission of social value of technology: A second potential source of bias in our estimates of the effect of lobbies on technology diffusion might arise from the omission of controls that measure the social value of new technologies. The technology gap between a technology and its predecessor is likely to be positively correlated with the social value of the new technology. The quality of institutions may reflect the sensitivity of the government to the social value of institutions. Therefore, we should expect that countries with "good" institutions are going to adopt policies that accelerate the (relative) diffusion of technologies without a close predecessor technology. Therefore, the omission of a measure of the social value of the new technology would result in a bias in the estimate of the interaction between the technology classification and the institutional variables. In particular, it would bias the estimates towards finding lower effects of good institutions in the diffusion of technologies with close predecessors. However, as described above, we find exactly the opposite. The degree of democracy, non-military regime and the effectiveness of the judicial system have a stronger (positive) effect on the diffusion of technologies with a close predecessor than without one. ${ }^{26}$

\footnotetext{
${ }^{25}$ Another variable that may affect the speed of diffusion of certain technologies is whether the government undertakes complementary investments. These investments are particularly important in transportation (roads, railroads, airports, harbours) and telecommunications. Omitting the magnitude of these government investments does not bias our estimates given the sector-specificity of the investments' importance.

${ }^{26} \mathrm{~A}$ similar argument could be made about the biases from the omission of measures of the willingness to accept change. It is not obvious to us how this variable would be correlated (if at all) with our institutional variables. One
} 
Omission of differential effect of controls in $X_{c t}$ : Another source of omitted variable bias in the estimates of the differential effects of the institutional variables on the technologies with close predecessors may be the omission of the interaction between the technology classification and the controls in $X_{c t}$. It could be argued that technologies with a close predecessor are more complementary to, say, human capital. Democratic institutions may be more effective in promoting human capital accumulation. Omitting the interaction between human capital measures and institutions might then generate a positive differential effect of institutional variables on technologies with a close predecessor for reasons other than lobbies. To explore this possibility, column 3 of tables 10 and 11 allow for a differential effect of the controls in $X_{c t}$ (income per capita, enrollment rates and electricity production) on the diffusion of the technologies with a predecessor (Table 10) and with a concentrated, competing predecessor (Table 11). The differential effects of institutions on the diffusion of technologies with a competing predecessor or with a concentrated, competing predecessor are largely robust to the presence of differential controls. The only institutional variable that becomes insignificant after allowing for a differential set of controls is judicial effectiveness. Hence, the differential effect of institutions on the diffusion of technologies with competing or concentrated, competing predecessors is not driven by the interaction between the technology classification and any of the correlates in $X_{c t}$, including human capital measures.

Beyond good vs. bad institutions: The fact that we can simultaneously identify the differential effect of all the institutional variables on the diffusion of the technologies with a competing or concentrated, competing predecessor raises the hurdle for the potential omitted variables since, to account for the estimated coefficients, they must be appropriately correlated with all the variables in $R_{c t}$. This is particularly difficult since we find that some measures of good institutions - democracy, judicial effectiveness and non-military regime - accelerate more the diffusion of technologies with competing predecessor, but one variable that is usually associated with good institutions - legislative flexibility - slows more the diffusion of this same group of technologies. ${ }^{27}$ This finding is perfectly possibility is that, as discussed in Acemoglu and Robinson [2002], bad institutions are more opposed to the adoption of more revolutionary technologies because these may threaten the political power of current leaders. If so, this omission would bias the estimates in favor of a larger effect of democracy, judicial effectiveness and military on the diffusion of technologies without a close predecessor; the opposite of what we find.

${ }^{27}$ The fact that the sign of the effect of many of the variables in $R_{c t}$ on the diffusion of technologies without a predecessor technology is different than for the technologies with a predecessor puts some additional constraints on the variance and correlations of the omitted variables with the endogenous and exogenous variables necessary to account for the estimated coefficients. 
natural, however, if lobbies constitute an important deterrent to the adoption of technologies with a competing predecessor.

Omission of Geography variables: To increase our confidence in the robustness and interpretation of the estimated differential effect of institutions across technology groups, we explore next some further omissions. For most of them, however, it is hard to argue why they should affect differentially the technology groups in a way that correlates with the differential effect that our institutional traits have.

The size of the country or its economy should have an effect on the diffusion of some of the technologies such as transportation and communication technologies. To explore whether they affect the estimated differential effects of institutions, column 4 includes as regressors the country area and population while column 5 includes real GDP. Of course, we allow these variables to have a differential effect on the technologies with a competing predecessor (Table 10) and with a concentrated, competing predecessor (Table 11). Though these measures of size have a significant differential effect on the diffusion of technologies with a predecessor technology, the differential effects of institutions on the diffusion of technologies with competing or with concentrated, competing predecessors are virtually unaffected.

In columns 6 and 7 we also allow for country fixed effects (column 6) and country fixed effects interacted with the dummy for technologies with a competing predecessor (column 7). This again does not have much effect on the size and significance of the estimates of the interactions between institutions and the predecessor technology dummy. The only relevant variable that becomes insignificant after allowing for different effects of the country fixed effects is the interaction between the effectiveness of the judiciary and the predecessor dummy. That is not very surprising since the judiciary variable is constant over time.

Source of identification: In column 8 we try to understand the source of the identification for the interaction between technologies and institutions. In particular, we explore whether we are obtaining any identification from the time-technology dimension or whether all the identification comes from the country-technology dimension. To do that, we include in the regression both country fixed effects and country fixed effects interacted with the dummy for technologies with previous competing technologies. After eliminating the country-technology dimension, the differential effects of the military dummy and of democracy on technologies that have a competing technology decline by approximately half and become insignificant. ${ }^{28}$ However, the differential effect of the flexibility

\footnotetext{
${ }^{28}$ The effectiveness of the judiciary measure drops from the regression because it only has cross-country variation.
} 
of the legislature remains negative and significant at the two percent significance level. This means we are identifying some of the differential effects of institutions on technology diffusion by exploiting the time series variation of the institutions.

Column 8 in Table 11 explores the source of the identification of the differential effect of institutions on the diffusion of technologies with concentrated, competing predecessors. As before, we do that by including, simultaneously, country fixed effects and country fixed effects interacted with the dummy for technologies with concentrated, competing predecessors. When doing that, we find that the estimate of the differential effect of legislative flexibility does not change while the estimate of the differential effects of democracy and the military dummy declines by about half. However, these differential effects of the institutional traits on technologies with close, concentrated predecessor technologies are still significant: legislative flexibility is significant at the one percent level while democracy and the military dummy are significant at the 7 percent level. Hence, we are identifying an important portion of the differential effects of institutions on technology diffusion through the time series variation of the institutions. This makes it even more unlikely that the estimates of the differential effects of institutions on technology diffusion are driven by omitted variables and reinforces the conclusion that lobbies are an important impediment to technology diffusion.

Reverse causality: Similar arguments lead to the conclusion that it is unlikely that reverse causality drives the observed differential correlation between diffusion for technologies with predecessor technologies and the institutional variables in $R_{c t}$. Namely, it is hard to argue why the speed of diffusion in the sectors with an incumbent technology, but not in the sectors without one, led to a democratic regime or to a legislative system where the authorities had no legislative independence. We believe that the previous discussion makes this argument very difficult to sustain. In addition,

it is important to note that the technologies we are studying are quite micro, and therefore the effect of their diffusion (or lack thereof) in aggregate macro variables, such as GDP and the labor market, may be quite limited.

\section{Concluding remarks}

Differences in the available technology across countries are believed to be a first order determinant of cross-country income per capita differentials. In this paper we have explored the empirical relevance of one of the determinants of technology diffusion. Namely, lobbying efforts by producers of incumbent technologies. We have observed that lobbies significantly slow the speed of diffusion 
of new technologies.

In addition, the findings of this paper also illustrate one channel by which institutions affect development. Namely, institutions affect the parties' incentives to engage in lobbying activities, lobbying slows technology diffusion, and technology affects crucially development. The empirical identification of this mechanism is a contribution to the institutions and growth literature.

This literature has followed two routes to progress: In standard regression analysis, it has tried to identify the effect of institutions on income per capita by controlling for elements other than institutions that may affect income per capita differences. This route has typically been unsuccessful because institutions become insignificant after including in the regression either a few reasonable controls or country fixed effects. A second route has argued that attenuation bias is responsible for this insignificance and has tried to find good instruments of institutions. This approach has been more successful, but it is still not clear whether the proposed instruments are truly valid. ${ }^{29}$ Further, since income per capita is highly correlated with many indicators of "good institutions," it is very hard to detect the specific institutional traits that drive income per capita differences with this instrumental variables approach.

This paper provides an alternative route to establishing empirically the link between institutions and development, which hinges on two pillars. First, the use of measures of diffusion for various technologies as dependent variables. Second, the identification of the effect of institutions by interacting institutions to a relevant ex-ante classification of technologies.

We believe that our approach has some interesting virtues. First, as we have argued above, it is very robust to omitted variable and reverse causality biases. Second, by using a multidimensional dependent variable with so much variation both over time and in the cross-section as technology diffusion, the test of the null that lobbies have no effect on technology diffusion is more powerful. Indeed, we have identified the effect of lobbies on technology diffusion through the differential effects of institutions on technology diffusion even after introducing country fixed effects and the interaction of country fixed effects with the a priori classification of technologies. Finally, with our approach we have been able to pinpoint some specific institutional traits that strongly affect technology diffusion. This step is very important for two reasons. First and foremost, it is critical to draw specific policy recommendations from this kind of empirical analysis. Second, we have observed that not all the institutional characteristics that are usually associated to advanced economies accelerate the speed

\footnotetext{
${ }^{29}$ See the debate between Acemoglu, Johnson and Robinson [2001] and Glaeser et al. [2004] and Acemoglu et al [2005].
} 
of diffusion of technologies. In particular, more flexibility of the legislative authority makes it easier for lobbies to induce him to raise political barriers to the diffusion of new technologies that ultimately slow their diffusion.

The strategy used to identify the role of lobbies on technology diffusion captures the barriers raised by incumbents that compete with new entrants in the product market. This is just one of the possible mechanisms by which interest groups (broadly understood) slow down the diffusion of new technologies. De Soto [1989], for example, claims that corrupt bureaucracies prevent the adoption of new technologies. Acemoglu and Robinson [2000] and [2002] argue that elites block the adoption of new technologies in order to preserve their political power. Finally, various authors have claimed that interest groups such as unions or elites may block the adoption of technologies that affect the labor market outcomes. One interesting line of research that we plan on pursuing in the future is to evaluate the empirical relevance of these mechanisms. Doing that will require increasing the number of technologies in our data set. For example, our data set only contains one labor saving technology (i.e. industrial robots).

The empirical strategy used in this paper can be applied to identify mechanisms other than lobbies through which institutions affect technology diffusion and income per capita. These exercises may provide us with a better understanding of the specific institutional traits that trigger engines of development such as technology adoption. If, as this and other papers suggest, institutions are important for development, identifying the likely consequences of specific institutional traits is as necessary for the advancement of poor countries as sequencing the DNA is for curing genetic diseases. 


\section{References}

[1] Acemoglu, D. and Robinson, J. [2000]: "Why Did The West Extend The Franchise? Democracy, Inequality, And Growth In Historical Perspective," The Quarterly Journal of Economics, MIT Press, vol.115 (4), Nov., 1167-1199.

[2] Acemoglu , D. and Robinson, J. [2000]: "Political Losers as a Barrier to Economic Development" American Economic Review Papers and Proceedings, volume 90, pp. 126-130.

[3] Acemoglu , D., Johnson, S. and Robinson, J. [2001]: "The Colonial Origins of Comparative Development: An Empirical Investigation," American Economic Review, Dec., 91, 1369-1401.

[4] Acemoglu , D. and Robinson, J. [2002]: "Economic Backwardness in Political Perspective" NBER wp \#8831

[5] Acemoglu, D. [2004]: "The Form of Property Rights: Oligarchic vs. Democratic Societies", mimeo.

[6] Acemoglu , D., Johnson, J., Robinson, J. and Yared, P. [2005]: "From Education to Democracy?" NBER wp \#11204.

[7] Adams, W. and Dirlam, J. [1966]: "Big Steel, Invention, and Innovation," The Quarterly Journal of Economics, vol. 80, no. 2, May, 167-89.

[8] Adsera A., Boix, C. and Payne, M. [2003]: "Are You Being Served? Political Accountability and Governmental Performance," Journal of Law, Economics and Organization, 19, Fall.

[9] Aghion, P. and Howitt, P. [1998]: Endogenous Growth Theory, Cambridge, Mass: MIT Press.

[10] Anchordoguy M. [2001]: "Nippon Telegraph and Telephone Company (NTT) and the Building of a Telecommunications Industry in Japan," Business History Review, vol.75, Autumn, p.507541.

[11] Archer G.[1938]: History of Radio to 1926, New York: The American Historical Society, American Book - Stratford Press: New York.

[12] Ayres R.U. and Miller, M. [1983]: "Robotic Realities: Near Term Prospects and Problems," 11, Vol. 47, Annals of the American Academy of Political and Social Sciences. 
[13] Besley, T. and Case, A. [1995]: "Does Electoral Accountability Affect Economic Policy Choices?: Evidence from Gubernatorial Term Limits," The Quarterly Journal of Economics, vol. 110, no.3, Aug., pp.769-798.

[14] Biggs, L. [1996]: The Rational Factory: Architecture, Technology and Work in America's Age of Mass Production, John Hopkins University Press: Baltimore, 1996.

[15] Brown, S. and Wright, T. [1981]: "Technology, Economics and Politics in the Modernisation of China's Coal Mining Industry: The First Phase, 1850-1895," Explorations in Economic History 18.1., pp. 60-83.

[16] Casson, H. N. [2004]: History of the Telephone, Fairfield, Iowa: 1st World Library.

[17] Coe, L. [1995]: "The Telephone and Its Several Inventors: A History," Jefferson, North Carolina: McFArland \& Company.

[18] Comin, D. and Hobijn, B. [2004]: "Cross-country Technology Adoption: Making the Theories Face the Facts", Journal of Monetary Economics, Volume 51, 38-83.

[19] Comin, D. and Hobijn, B. [2005]: "Lobbies and Technology Diffusion", NBER wp \# 11022.

[20] Comin, D., B. Hobijn and E. Rovito [2006]: "Five Facts you Need to Know about Technology Diffusion," NBER wp \# 11928.

[21] Curcio, V. and P. Curcio [2000]: Chrysler: The Life and Times of an Automotive Genius, Oxford University Press, Oxford, UK.

[22] Curran J. and J. Seaton [1981]: Power without Responsibility: The press, broadcasting and new media in Britain, Routledge: London.

[23] De Soto, H. [1989]: The Other Path: Invisible Revolution in the Third World, New York: Harper and Row.

[24] Ferejohn [1986]: "Incumbent Performance and Electoral Control," Public Choice 50, 5-25.

[25] Fisher D. A. [1963]: The Epic of Steel, Harper and Row, New York.

[26] Fogel, R. W. [1964]: Railroads and American Economic Growth: Essays in Econometric History, Johns Hopkins Press, Baltimore and London. 
[27] French, Gilbert J. [1862]: The Life and Times of Samuel Crompton of Hall-in-the-Woods, Inventor of the Spinning Machine Called the Mule. Charles Simms and Co, Manchester.

[28] Glaeser, E., R. La Porta, F. Lopez-de-Silanes, and A. Shleifer [2004]: "Do Institutions Cause Growth?" Journal of Economic Growth, Vol. 43, pp 271-303.

[29] Gallup Organization [1993] The Motorola Cellular Impact Survey. Princeton, NJ.

[30] Helpman, E. and G. Grossman [1994]: "Protection for Sale" American Economic Review, vol. 84, 4, pp. 833-50.

[31] Hsieh, C. and P. Klenow [2003]: "Relative Prices and Relative Prosperity", NBER working paper No. 9701, May 2003.

[32] Holmes, T., and J. Schmitz Jr. (2001), "A Gain from Trade: From Unproductive to Productive Entrepreneurship", Journal of Monetary Economics, 47, 417-446.

[33] Hofman [1913]: General Metallurgy, McGraw-Hill, New York.

[34] Huffington, P. and N. Clifford [1939]: "Evolution of Shipbuilding in Southeastern Massachusetts." Economic Geography. Vol. 15, No. 4 (Oct ), pp. 362-378.

[35] Ike, N. [1955]: "The Pattern of Railway Development in Japan" The Far Eastern Quarterly, Vol. 14 No. 2 (Feb.) pp. 217-29.

[36] Kelley, L., Jugenheimer, D. [2003]: Advertising Media Planning: A Brand Management Approach. M.E. Sharpe, New York.

[37] Kinder, C.W. [1891]: "Railways and Collieries of North China," MICE, Minutes and Proceedings of the Institutions of Civil Engineers, Vol.103, 1890-1891, pp. 278-306.

[38] Klemm, F. [1964]: A History of Western Technology, MIT Press, Cambridge, MA.

[39] Krusell P., and V. Rios-Rull [1996]: "Vested Interests in a Positive Theory of Stagnation and Growth" The Review of Economic Studies, Vol. 63, No. 2. (Apr.), pp. 301-329.

[40] Kunicova, J. and S. Rose-Ackerman, [2002]: "Electoral rules as constraints on corruption," mimeo, Yale University, New Haven, CT. 
[41] La Porta, R., F. Lopez-de-Silanes, A. Shleifer and R. Vishny [1998]: "Law and Finance," Journal of Political Economy.

[42] Liddel, D.M. [1916]: The Metallurgists and Chemists' Handbook, McGraw-Hill Book Co.

[43] Lijphart, A. [1994]: Electoral Systems and Party Systems, Oxford University Press.

[44] Lijphart, A. [1999]: Patterns of Democracy: Government Forms and Performance in ThirtySize Countries, Yale University Press.

[45] Locklin, D. P. [1960]: Economics of Transportation, 5th Ed., Homewood, Illinois: R.D. Irwin.

[46] Maggi, G. and P. Goldberg [1999]: "Protection for Sale: an empirical investigation," The American Economic Review, vol. 89, (Dec.) pp. 1135-1155.

[47] Mason, M. [1992]: American multinationals and Japan: The political economy of Japanese capital controls, 1899-1980, Harvard University Press, Cambridge, MA.

[48] Mokyr, J. [1990]: The Lever of Riches: Technological Creativity and Economic Progress, New York: Oxford University Press.

[49] Myerson, R. [2003]: "Effectiveness of Electoral Systems for Reducing Government Corruption: A Game Theoretic Analysis," Games and Economic Behavior, No. 5, 118-132.

[50] Gomez-Mendoza, A. [1989]: Ferrocarriles y Cambio Economico en Espana (1855-1913), Alianza Editorial, Madrid.

[51] Odagiri, H., and A. Goto [1996]: Technology and Industrial Development in Japan, Oxford University Press, Oxford, UK.

[52] Oliver, J. [1956]: History of American Technology, Ronald Press, New York.

[53] Olson, M. [1984]: The Rise and Decline of Nations: Economic Growth, Stagflation, and Social Rigidities, Yale University Press.

[54] Parente, S. and E. Prescott [2000]: Barriers to Riches, MIT Press, Cambridge, MA.

[55] Phelps, C. [1969]: "The Persian Gulf Submarine Telegraph of 1864," The Geographical Journal, Vol. 135, No. 2. (Jun.), pp. 169-190. 
[56] Persson, T. and G. Tabellini [2000]: Political Economics. Explaining Economic Policy, MIT Press, Cambridge and London, ch.9.

[57] Persson, T., G. Roland, and G. Tabellini [2000]: "Comparative Politics and Public Finance," Journal of Political Economy, 108, 1121-1161.

[58] Persson, T., G. Tabellini and F. Trebbi [2003]: "Electoral Rules and Corruption," mimeo, Stockholm University.

[59] Pollard, S. and P. Robertson, [1979]: The British shipbuilding industry 1870-1914, Harvard University Press, Cambridge, MA.

[60] Powell, G. [2000]: Elections as Instruments of Democracy, Yale University Press.

[61] Rajan, R. and L. Zingales [1998]: "Financial Dependence and Growth" American Economic Review, 88: 559-586.

[62] Rhodes, F. [1929]: Beginnings of Telephony, Harper \& Brothers, New York and London.

[63] Saxonhouse, G. R. and Wright, G. [2000]: "Technological Evolution in Cotton Spinning, 18781933," mimeo.

[64] Sekiguchi, S. [1986]: "Gijutsu Yunyusha to Shiteno Nihon" [Japan as a Technology Importer], in Sekiguchi Sueo and Tran Van Tho eds., Chokusetsu Toshi to Gijutsu Iten, Tokyo: Japan Center for Economic Research.

[65] Sichel, D. [1997] The Computer Revolution: An Economic Perspective. Washington D.C.: The Brookings Institute.

[66] Solymar, L. [1999]: Getting the Message: A History of Communications, New York: Oxford University Press.

[67] Smith, F. [2004]: Understanding Reading: A Psycholinguistic Analysis of Reading and Learning to Read, Mahwah, New Jersey: Lawrence Erbaum Associates.

[68] Stern B. J [1937]: "Resistances to the Adoption of Technological Innovations." In Technological Trends and National Policy, US Government Printing Office, Washington, DC. 
[69] Thompson, R. [1947]: Wiring a Continent: The History of the Telegraph Industry in the United States 1832-1866, Princeton University Press, Princeton, NJ.

[70] Tirole, J.[1988]: The Theory of Industrial Organization, MIT Press, Cambridge, MA.

[71] Wallace, A. and F. Rockdale [1972]: The Growth of an American Village in the Early Industrial Revolution, Knopf: New York.

[72] Walton, P. [1925]: The Story of Textiles, Walton Advertising and Printing Co: Boston.

[73] Warner L. [1962]: "Railroads Rates and the Growth of Coal Trucking in Ohio,". Land Economics, Vol. 38, No. 3, pp. 231-239.

[74] Wells, A. and E. Hakanen [1997]: Mass Media and Society, Ablex Publishing, Westport, CT.

[75] Weiss, E. [2003]: Chrysler, Ford, Durant and Sloan: Founding Giants of the American Automotive Industry, McFarland \& Company: North Carolina. 


\section{Appendices}

Appendix 1 classifies technologies according to the productivity differential between a given technology and its proceeding technology. Appendix 2 documents the size of the sunk costs necessary to implement or produce the technologies that preceded those technologies that implied a relatively small productivity gain.

\section{Appendix 1: Productivity Differentials}

We first describe the new technology and the ways in which it dominated its predecessor technology. We then present studies that have tried to the quantify productivity differential between the new and old technology. Technologies improve quickly after their invention, so we compute the productivity differential approximately 30 years after the new technology's invention date.

It is worth noting that, although the productivity differential between two technologies is a technological attribute, some technologies may have differentials that vary according to geography. Given that most of the information about productivity differentials is specific to only a few countries, this could be a problem for the classification. This problem is not of practical relevance, however, because, for most of the technologies, the differential is either in the hundreds or under three. Given the difference in magnitudes considered, it is difficult to argue that geographical variation will significantly alter the classifications.

\section{Textiles}

\section{Ring Spindles}

Cotton textiles became the first truly global industry after a series of innovations mechanized spinning and weaving, two of the most important cotton activities. In 1770, Hargreaves invented

the spinning Jenny, and in 1779, Crompton designed the spinning mule. The first ring spindles were simultaneously invented by John Thorp and Charles Danforth in 1828. The main technical difference between the ring and mule spindles is that the ring spins continuously, while the mule spins intermittently.

According to Saxonhouse and Wright [2000], "Consistent with the trend in modern scholarship, our reading of the evidence was that on close examination, there was no simple right or wrong choice [between ring and mule spindles] prior to the technical breakthroughs in ring spinning [...] that came after 1913" (p. 2). "Rather than seeing an older, 'mature,'technology supplanted by a 
more advanced modern form, we observe two technological paradigms in competitive coexistence, each on capable of supporting ongoing productivity growth through complementary improvements in machinery, organization and workforce skills" (p. 10).

Saxonhouse and Wright provide the average speed of new mule and ring spindles in a sample of 15 countries for various periods up to 1920. As late as 1914, the average spinning speed of new mule spindles was $9600 \mathrm{rpm}$, while that of ring spindles was $8900 \mathrm{rpm}$. This data indicates the productivity differential between ring and mule spindles was relatively small.

\section{$\underline{\text { Steel }}$}

\section{Bessemer}

Prior to the invention of the Bessemer process, steel was produced with crucibles. Wrought iron bars were broken up and heated in clay crucibles, each holding at most 40 to 50 pounds of metal. Ten to 15 days were then devoted to converting the iron into steel, which required large quantities of fuel. Consequently, crucible steel was expensive, selling for $£ 50$ to $£ 60$ per ton.

Bessemer's process avoided these costly and time-consuming steps by converting pig iron directly into steel. Pig iron contains excessive amounts of carbon and other elements (such as silicon,

phosphorus and sulphur), which make it brittle. This carbon content can be drastically reduced, and the other elements can be burned out by oxidation, thus converting the iron into steel. Bessemer used this process by developing a converter that had many small holes in its base allowing admission of an air blast that oxidated the molten iron.

The Bessemer converter brought an unprecedented productivity improvement over the crucible. It cast five tons of steel in 20 to 30 minutes, while the crucible process took 14 to 15 days to obtain only 40 or 50 pounds of steel (Fisher [1963] p. 117).

\section{Open Hearth and Blast Oxygen}

Subsequent innovations in steel production generated much smaller productivity improvements than the Bessemer furnace did. Open hearth furnaces did not significantly improve the productivity of the Bessemer converter, while blast oxygen furnaces were only 2.5 times more productive than open hearth furnaces (Adams and Dirlam [1966]).

\section{Electric Arc}

Electric arc furnaces were entirely different from previous innovations in steel production. The invention of the electric arc allowed for the first time the efficient production of the stainless steel 
used in cookware, cutlery, hardware, surgical instruments, major appliances, industrial equipment and building materials for skyscrapers. As the electric arc was the first technology to produce stainless steel, it was immeasurably more productive than any of its predecessors, including the blast oxygen furnace.

\section{Telecommunications}

\section{Telegraphs}

The telegraph revolutionized communications, achieving an increase in communication speed no development in communications has achieved since. Between 1840 and 1850, the telegraph cut costs by a factor of 100 and reduced elapsed time per word transmitted by a factor of three thousand, from ten days to five minutes for a one-page message between New York and Chicago (Sichel [1997] p. 127).

\section{Telephones}

The productivity increase between the telephone and the telegraph is relatively small and, at times, insignificant, depending on the task being completed. Solymar [1999] and Smith [2004] report that it took about six times longer to tap a message, then translate the Morse code into words than it took to read it by telephone. Coe [1995], however, estimates that it took about the same time to dispatch trains by phone and by the telegraph. Additionally, Casson [2004] cites a United Press study that estimates it also took the same time to dispatch news to 10 cities by phone and by telegraph. Taking the average of these three tasks, we estimate that the telephone increased communications productivity by a factor of three.

\section{Cell Phones}

Unlike the telephone, the mobile phone significantly increased communications productivity. In 1993, Gallup conducted a survey of cell phone users asking how much their productivity increased by using a mobile phone instead of a fixed phone. Responders reported an average productivity increase of 34 percent.

\section{$\underline{\text { Mass Communications }}$}

\section{Newspapers}

Newspapers did not have a clear predecessor, and thus can be classified as having an arbitrarily large productivity differential. 


\section{Radios and TVs}

Determining the productivity differentials between newspapers, radios and TVs is difficult because each technology affected the productivity of mass communication, but also added an entirely new dimension to the mass communication industry. If they are considered only alternative ways of communicating information, the relevant productivity measure is the amount of information they convey per unit of effort on behalf of the reader, listener or viewer.

Studies comparing the recall rates for each media typically conclude that recall rates are higher with newspaper than with radios or televisions. For example, Hooper Inc. conducted a study in 1969 that showed the following average unaided recall rates: $34 \%$ for magazine ads, $28 \%$ for newspaper ads, $19 \%$ for prime TV commercials and 14\% for radio commercials (Kelley and Jugenheimer [2003] p. 38.)

To compute a complete productivity measure, one should also consider the difference in energy used by the reader, listener or viewer. Studies of this have shown that a person's metabolic rates are lowest when watching TV and lower when listening to radio than when reading.

These productivity measures are still incomplete, however, because they ignore the fact that both radios and TVs introduced to mass communication the ability to transmit sound and image over thousands of kilometers. In this sense, it can be argued that radios and TVs are horizontal, rather than vertical, innovations and that neither have a predecessor technology. To quantify this, one could measure the bandwidth of radios and TVs, which captures amount of information transmitted in sound and image. AM radio has 10 Kilohertz of bandwidth, while FM radio has $200 \mathrm{kHz}$ and TV has $6000 \mathrm{kHz}$ (Wells and Hakanen [1997]).

In practice, we will consider televisions and radios as technologies that both are and are not subject to the effects of institutions through lobbying. First we will consider them as vertical innovations that are sensitive to the effects of institution trough lobbying by classifying radios and TVs as technologies with small productivity differentials based on their respective recall rates. Then, in Appendix 2, we recognize that the sunk costs of setting up a newspaper or radio station are small relative to other sunk costs we consider (for example, the cost of setting up a car factory or shipyard). Therefore, both radios and TVs can be classified as a technology without a predecessor technology that has large rents to defend and is technologically close to the new technology. This permits us to explore the robustness of our estimates to the classification of this particular group of technologies that is especially difficult to make.

\section{Information Technology}




\section{PCs and Robots}

PCs and robots are radical technologies both because of the productivity improvements in using them to complete old tasks (ex: word processing) and, more importantly, because of the new tasks that became feasible with their invention.

With respect to faster completion of old tasks, the University of Indiana in 1981 concluded that word processing with a PC instead of a typewriter would reduce the cost of typing by 56 percent. Several studies have also estimated the cost reduction from using robots in car manufacturing

plants. Ayres and Miller [1983] document productivity increases ranging from $30 \%$ for high capacity plants to $330 \%$ for low capacity plants, and these increase to $80 \%$ for high capacity and $560 \%$ for low capacity when plants use robots with computer aided design (CAM) capabilities. Productivity increases in low capacity plants are significantly higher because they can better exploit the flexibility gains that come from using robots.

In addition to replacing typewriters and manual labor, robots and PCs also allow the completion of many new tasks. For example, robots made operation of hazardous materials in extreme environments safer, and computers greatly reduced the cost of completing computations and organizing and distributing information. They also revolutionized graphic design.

\section{Transportation}

\section{Railways}

In some countries, railways constituted a revolution in both passenger and freight transportation. In the pre-rail era, for example, it took two to four days to travel the 90 miles that separate New York from Philadelphia (Oliver [1956]), giving an average speed of about two miles per hour. Within a few years after the introduction of the railroad, average passenger transportation speeds were 10 times higher than that.

Even larger was the impact of railroads in freight transportation in countries where the only predecessor to railroads was an ordinary road. Freight trains run slower than passenger trains, but transported hundreds of tons of freight at once. In the mid 1850s, the average freight train in New York transported over 200 tons of freight and, as early as 1840, the Reading locomotives transported over 400 tons of coal at average speeds of $10 \mathrm{mph}$. In contrast, the size of freights transported by road was below 10 tons.

Locklin [1960] studied the relative cost of transporting corn and wheat in railroads vs. with ordinary roads. For very short distances (i.e. less than 10 miles), transportation costs for railroads 
and roads were about the same, but as the distance increased, railroads became significantly more economical. For example, transporting corn across 300 miles was 10 times cheaper by rail than by ordinary roads.

In countries with canal systems, however, railroads did not bring such a significant increase in productivity to freight transportation, although they were still revolutionary in the realm of passenger transportation. Canal transportation was cheaper, but slower, than rail transportation (Oliver [1956]). In 1852 rail shipments from Cincinnati to New York City took from six to eight days, about a third of the time required for service via the canals, Lake Erie and the Hudson River (Stover [1997]). Fogel [1964] estimates that railways reduced the cost of transporting cargo relative to canals by slightly less than a factor of two.

\section{Cars and Trucks}

Cars were first produced in Europe in the late 1800s - the first internal combustion engine was introduced in 1863 - and came to the U.S., where they underwent the greatest development, in the 1890s. From their invention through the 1950s, cars were less productive than trains, first because cars took several years to even acquire enough power and reliability over long distances to compete with the speed of trains and then because of the slow pace of road construction and improvements. For example, when cars were first invented, it was quite an achievement that an Oldsmobile covered 820 miles in seven and a half days, sometimes driving at "train speeds of 35 miles per hour "(Curcio and Curcio [2000] p.152). By 1904, Henry Ford's car was setting land speed records of $91.4 \mathrm{mph}$, but even this did not qualify the automobile to compete with the train (Weiss [2003]). This was predominately because, although cars were more convenient for traveling quickly over short distances - for example, doctors frequently used them to make house calls - they were not built to maintain their speed or hold up for long-distance travel, as trains were. As Weiss explains, "At the start of the 1920s, 90 percent of the cars were open touring cars" ([2003] pp. 47-8).

Compared to cars, trucks showed more of a productivity improvement over trains; however, they did not immediately dominate trains in all arenas of freight transportation. They were more efficient than trains in very short distances, but when transporting cargo for distances above 80 miles, rail transportation was cheaper than road transportation, even when using 20-ton trucks (Warner [1962] p. 237).

\section{Planes}

The first commercial planes appeared in the late 1920s and, by 1925, planes could cross the U.S. 
in about 48 hours. In 1936, the DC-3 could transport 900 pounds of cargo and 21 passengers at a speed of $180 \mathrm{mph}$. The Stratolier, which appeared in 1938, transported 33 passengers at $250 \mathrm{mph}$. These speeds, while impressive, are still less than five times the speed of the fastest trains, which in 1894 traveled at an average speed of about $55 \mathrm{mph}$ (Oliver [1956]). As early as 1889, Nellie Bly traveled from San Francisco to New York by train in less than four days, despite being unable to catch the fast train from Chicago to New York (Oliver [1956]). Planes were not, then, sufficiently more productive than trains.

\section{Shipping}

\section{Sailing Ships}

The 1840s and 50s saw the development of a new generation of sail ships: the clippers, the first of which was the "Rainbow," designed by John Griffith in 1841. The innovations in the Rainbow's design included a "lengthening of the bow into graceful upward curves, making it concave rather than convex in contour, and thus enabling it to slice like a knife through the waters" (Oliver [1956] p. 196). The Rainbow was a 750-ton vessel and was by far the smallest clipper of its time. Subsequent clippers weighed anywhere from 908 tons (the "Sea Witch") to 4000 tons (the "Challenge," built in 1853).

Clippers were famous for their speed. The "Lightning" traveled 436 miles in 24 hours, or at an average of 18 miles per hour. On one occasion, she traveled from New York to Liverpool in 13.5 days. The "Flying Cloud" sailed from New York to San Francisco in 89 days, covering 433 miles in one day alone. The "Sovereign of the Seas" logged 495 statue miles in one day and for four consecutive days covered an average of 378 miles per day. Finally, the "Oriental" made the passage from New York to Hong Kong in 81 days (Oliver [1956] p. 197).

\section{Steam Ships}

The development and subsequent improve of steam ships were long, arduous tasks. The first steam ships were used primarily for river navigation because ocean steam navigation presented many technological problems. For example, the paddle-wheel propulsion system proved unsatisfactory on rough waters; the main lubricant available at the time, animal oils, became rancid; the daily task of blowing out the boilers became a hazard on the ocean because the vessel idled during the process; the supply of coal needed for a transoceanic voyage occupied too much cargo space; and marine engines were poorly developed. These problems made commercial use of steam ships for ocean and transoceanic routes impractical for years after the steam ships' invention. 
The problems were gradually overcome with a series of innovations, including the replacement of the paddle-wheel with the screw propeller. It was not until the end of the century, however, that the fastest steam ships sailed at speeds beyond the reach of the clippers. In 1893, the "Columbia" held the naval record of continuous sea speed at 22.8 knots (miles per hour) for four hours and an average of 18.4 knots while crossing the Atlantic (Oliver [1956]). 


\section{Appendix 2: Size of sunk Costs of Production of Predecessor Technologies}

In general it is relatively easy to classify the old technologies according to the size of the sunk costs of their production. Following is documentation based on a few examples of the sunk costs of producing predecessor technologies whose productivity is relatively close to the productivity of their succeeding technologies.

\section{$\underline{\text { Textiles }}$}

\section{Mule Spindle (predecessor to ring spindle)}

The first mule was invented in a home in 1779 by a 26-year-old boy (Walton [1925]); similarly, the second mule was erected in a loft above a school house (French [1862]). The small, unsophisticated settings for the construction of these first mules indicate that producing mules required small sunk costs. Consistent with this estimate, the mule had a low purchase cost ${ }^{30}$ compact form and inconsiderable weight and was most frequently found in "a moderate-sized room of an ordinary dwelling-house" (French [1862]). In fact, after it was invented, "[the mule] was many years rather a domestic implement than a portion of the great modern factory system" (French [1862]).

\section{$\underline{\text { Steel }}$}

\section{Bessemer (predecessor to open hearth)}

Liddel [1916] reports costs of setting up various types of metallurgical plants from Hofman [1913] at the turn of the century. The cost of building an acid Bessemer plant with capacity to produce 2000 tons of steel per day was $\$ 900,000$.

\section{Open Hearth (predecessor to blast oxygen steel furnace)}

Liddel [1916] also reports that the cost of building an acid open hearth plant able to produce 1000 tons of steel per day was $\$ 1.5$ million.

\section{$\underline{\text { Telecommunications }}$}

\section{Telegraph (predecessor to telephone)}

To transit telegrams, it is necessary to set up a complex wire network, which supposes a large sunk cost to telegrams. In 1848, the average cost of constructing the six regions in the Atlantic, Lake and Mississippi line - Atlantic and Ohio; Pittsburg, Cincinnati and Louisville; Ohio and

\footnotetext{
${ }^{30}$ Mules with 300 spindles were still relatively cheap and sold for only $\$ 345$ (Wallace [1972]).
} 
Mississippi; Ohio, Indiana and Illinois; Lake Erie; and Illinois and Mississippi - was $\$ 150$ per mile, or $\$ 240$ per Km (Thompson [1947]). Additionally, construction of the New York to Erie line was projected in 1848 to cost $\$ 250$ per mile for the first wire and an additional $\$ 100$ for each wire after that (Thompson [1947]). In 1850, there were about 4000 miles of wire in operation in the UK. The quality of the lines in the UK was higher than in the US. This emphasis in quality lead to higher construction costs. In some cases, these amounted to $\$ 600$ per mile. Finally, the total cost of manufacturing, laying and bringing into working order the Persian Gulf submarine telegraph line, built in 1964, was $£ 411,751$ (Phelps [1969]).

\section{Telephone (predecessor to Cell phone)}

Similar to telegrams, setting up the telephone lines necessary for telephonic communication was very costly. In its 1887 report to shareholders, The American Bell Telephone Company announced that it "intended to complete this year the lines between New York and Boston, to extent from Albany towards Buffalo and to build a line from Chicago to Milwaukee. The estimated cost of about $\$ 1,000,000 "$ (Rhodes [1929]). By 1888, The American Bell Company had constructed telephone lines with 26,038 miles of wire, which covered a distance of approximately 20 times less than the actual wire length. These lines cost approximately $\$ 2,200,000$, or $\$ 84$ per mile of wire. In total, it cost The American Bell Company spent over $\$ 35$ million to build lines, build plants to meet growing customer demands, upgrade existing plants' technology and install underground wires (Rhodes [1929]).

In 1886, building a pole line between New York and Philadelphia with 70 wires and 24 copper wires cost approximately $\$ 215,000$ (Rhodes [1929]).

\section{Mass Communication}

\section{Newspaper (predecessor to radio)}

As evidenced by the large number of radical and mainstream newspapers that have been circulated since the printing press was invented, the cost of purchasing a printing press has always had a relatively low sunk cost. In the 1830s, for example, most radical, unstamped papers were printed on hand presses, which cost as little as $£ 10$ to acquire.

The low sunk cost of buying a printing press has persisted even while printing presses have experienced significant technological advancements. After 1836, for example, most radical presses began using the technologically superior steam press. Even then, papers like The Northern Star cost only £690 to start (Curran and Seaton [1981]). 
In 1912, after the industrialization of the press, newspapers still required only a small sunk cost to start. For example, The Daily Citizen began in 1912 with only £30,000 and the Daily Herald used only $£ 300$ to start and, with the help of public subscriptions, achieved a circulation of almost 250,000 (Curran and Seaton [1981]).

\section{Radio (predecessor to TV)}

Similar to newspaper, the low sunk cost of setting up a radio station is immediately evident in the large number of radio stations that opened in the U.S. in the 1920s. As Archer describes it, "The advent of radio broadcasting created one of the most extraordinary booms in the history of the American people. From all over the United States orders for equipment for prospective radio broadcasting stations came pouring in to the manufacturers of such apparatus". According to Archer [1938], from August of 1921 to May of 1922, at least 306 radio stations began in the U.S. alone. This number is unsurprising, given that the total cost of setting up a "modest" radio station was only around $\$ 50,000$ (Archer [1938]).

\section{Transportation}

\section{Canal (predecessor to freight trains)}

Building a canal comes with a very large sunk cost, which is demonstrated in the following example.

In the late eighteenth century, the U.S. planned to create a canal that would provide transportation from the East Coast, past the Appalachian Mountains and into the interior of the country. New York State funding was approved for the project in 1816 and, one year later, construction on what is now known as the Erie Canal began. Built without the use of heavy machinery, but rather with the manual labor of British, German and Irish immigrants, the canal was finished in 1825 at a total cost of $\$ 7$ million.

See Table A.1 for examples of the cost of building canals in the US, the UK, Canada and France.

\section{Railway (predecessor to trucks, cars and planes)}

Establishing a rail network came at a very high sunk cost when railways were first developed in the 1800 s and continues to carry with it high costs as railways are updated and new tracks are built today. Dodge described the cost and labor required to build the Union Pacific Railroad [1965]. When the project was initially considered in 1836, bills were introduced in Congress suggesting as much as $\$ 96$ million for the railroad' s construction. Once construction finally began, the Union Pacific was funded by government bonds paying $\$ 48,000$ per mile for the first 150 miles west of 
Cheyenne and $\$ 32,000$ per mile thereafter. Additionally, building the railroad required at one time the use of 10,000 animals to haul supplies and consistently required from 8,000 to 10,000 laborers.

Lewis Clement, one of the pioneers of the Union Pacific and Central Pacific railroads also discussed the costs associated with building the two railroads. According to Clement, in 1868, it cost $\$ 51.97$ to ship a ton of rail to Sacramento, which, added to the cost of the rail itself, totaled $\$ 143.67$ per ton of rail. This cost did not include transportation of the rail up the Sacramento River (Ambrose [2000]).

Additionally, construction of the Union Pacific railroad required the construction of snow sheds and galleries over the rack running through the Sierra Nevada to keep snow of the tracks in the winter. According to Galloway [1950], "About 2,500 men were employed and six trains were used to bring the material" (p. 150). When completed, the sheds and galleries covered 37 miles of track, used $65,000,000$ feet of lumber and cost a total of $\$ 2,000,000$.

Other, less famous railroads came at similarly large costs. A railroad in England that was constructed in the 1820s and ran from Liverpool to Manchester in England cost $\$ 187,495$ per mile (Galloway [1950]). The Long Island Railroad, constructed in the late 1800s, cost a total of $\$ 1,730,000$ to build (Smith [1958]).

Even today, updating old track and building new track requires a high sunk cost. In Australia, for example, the cost of a new 'T-line' railway from Goulburn to Yass cost $\$ 127$ million (Laird $[2001])$.

\section{Cars (predecessor to planes)}

As with previous transportation technologies, cars also require a high sunk cost to produce. In the early 1900s, Ford constructed a plant on the River Rouge at a cost of $\$ 3.5$ million and a second plant in Kearny, New Jersey, which cost $\$ 2.5$ million (Biggs [1996]). By the 1950s, the cost to Ford of updating its plants to produce its popular 1953 model car was an enormous $\$ 1$ billion (Weiss $[2003])$.

Other large car producers incurred similarly high sunk costs. In 1922, for example, William Durant purchased a plant in Elizabeth, New Jersey for \$5,525,000, and, during the 1930s, GM spent $\$ 346$ million in new plants and equipment (Weiss [2003]).

\section{Shipping}

\section{Sailing Ships (predecessor to steam and motor ships)}


From the beginning of the shipbuilding industry through at least when steam ships were invented, it required a high sunk cost to begin producing sailing ships. Huffington and Clifford [1939] describe the many restrictions on a yard' s location, which put a high price on the production of sailing ships that was incurred even before the yard is built. To keep the costs of transportation down, they explain that shipyards needed to be located on a river or estuary, allowing ships to be built "without fear of wreck" (Huffington and Clifford [1939] p.363). At the same time, however, the yards needed to be close to bog ore and forge sites, which provided iron for ship fittings, and forests abundant in oak and pine, which provided wood for the hulls and masts. In addition to these requirements, shipyards also needed a large, flat area that afforded room to construct several-hundred ton ships. Combined, these limitations left few viable options for the location of shipyards, which meant only a few producers could successfully enter the shipbuilding industry.

Huffington and Clifford also explain that, by 1815, timber supplies near the shipyards were exhausted, forcing builders to purchase timber located further and further away and incur substantial transportation costs. In one instance, "It was necessary for a certain builder to purchase an entire woodlot, located some twenty miles inland, in order to get a single tree suitable for the forming of 'knees"' (Huffington and Clifford [1939] p.368).

The high cost of building a yard to produce steam ships speaks to the high costs involved in producing sailing ships. Because steam and sailing ships are around the same size and require many of the same materials (by the time steam ships were invented, many sailing ships were made of steel, as well as wood), the yard specifications for the two ships types were similar. Thus, specific measures of the costs involved in building a steam shipyard, which are more widely available than those of setting up a sailing shipyard, can be used as a proxy to get a general understanding of the costs of starting sailing shipyard. In Britain in 1900, a graving dock to release ships into the water cost approximately $£ 100,000$. More generally, the value of all the shipbuilding materials in the Clydebank (Britain) yard of John Brown and Company was £131,220 in 1899 and £200,691 in 1910 (Pollard and Robertson [1979]). 
Table 3: Technologies and Countries in Sample

Period covered: 1788-2001

TECHNOLOGIES

\begin{tabular}{|c|c|c|c|}
\hline I. & Textiles & Competing Predec. & Concen. Comp. Predec \\
\hline 1. & Fraction of spindles that are ring spindles & Yes & No \\
\hline II. & Steel & & \\
\hline 2. & Tons of steel produced with Bessemer over GDP & No & No \\
\hline 3. & Tons of steel produced with Open Hearth over GDP & Yes & Yes \\
\hline 4. & Tons of steel produced with Blast Oxygen over GDP & Yes & Yes \\
\hline 5. & Tons of steel produced with Electric Arc over GDP & No & No \\
\hline$\underline{\text { III. }}$ & Telecommunications & & \\
\hline 6. & (Log.) Telegrams per capita & No & No \\
\hline 7. & (Log.) Telephones per capita & Yes & Yes \\
\hline 8. & (Log.) Mobile phones per capita & Yes & Yes \\
\hline$\underline{\mathrm{IV}}$. & Mass communication & & \\
\hline 9. & (Log.) Newspapers per capita & No & No \\
\hline 10. & (Log.) Radios per capita & Yes & No \\
\hline 11. & (Log.) TV's per capita & Yes & No \\
\hline V. & Information technology & & \\
\hline 12. & (Log.) Personal computers per capita & No & No \\
\hline 13. & (Log.) Industrial robots over GDP & No & No \\
\hline VI. & Transportation & & \\
\hline 14. & $\overline{\text { (Log.) Freight traffic on railways (TKMs) over GDP } 21}$ & Yes/No & Yes/No \\
\hline 15. & (Log.) Passenger traffic on railways (PKMs) over GDP & No & No \\
\hline 16. & (Log.) Trucks per unit of real GDP & Yes & Yes \\
\hline 17. & (Log.) Passenger cars over GDP & Yes & Yes \\
\hline 18. & (Log.) Aviation cargo (TKMs) over GDP & Yes & Yes \\
\hline 19. & (Log.) Aviation passengers (PKMs) per capita & Yes & Yes \\
\hline VII. & Merchant shipping & & \\
\hline 20. & Share of steam and motorships in merchant fleet tonnage & Yes & Yes \\
\hline \multicolumn{4}{|c|}{ COUNTRIES } \\
\hline & $\begin{array}{r}\text { Australia, Austria, Belgium, Canada, Denmark, Finland, } \\
\text { Ireland, Italy, Japan, Luxembourg, Netherlands, Ne } \\
\text { Spain, Sweden, Switzerland, United King }\end{array}$ & $\begin{array}{l}\text { France, Germany, } \\
\text { Zealand, Norway, } \\
\text { om, United States }\end{array}$ & $\begin{array}{l}\text { reece, Iceland } \\
\text { Portugal }\end{array}$ \\
\hline
\end{tabular}

${ }^{21}$ Yes where canals are available. No, otherwise. 
Table 4: Technological distance between technologies and predecessors

\begin{tabular}{|c|c|c|c|c|}
\hline \multirow[t]{2}{*}{ New Technology } & \multirow[t]{2}{*}{ Previous Technology } & \multicolumn{2}{|c|}{ Technological Distance } & \multirow[b]{2}{*}{ Reference } \\
\hline & & Vertical & Horizontal & \\
\hline \multicolumn{5}{|l|}{ Textiles } \\
\hline Ring Spindles & Mule Spindles & Avg. Speed: Mules 9.6, Ring 8.9 & & Saxonhouse and Wright [2000] \\
\hline \multicolumn{5}{|l|}{$\underline{\text { Steel }}$} \\
\hline Bessemer & Crucible Steel & Increase in output per worker by a factor of over 500000 & & Fisher [1963] \\
\hline Open Hearth & Bessemer & Increases productivity by less than 2.5 -fold & & Adams and Dirlam [1966] \\
\hline Blast Oxygen & Open Hearth & Increases productivity by 2.5 -fold & & Adams and Dirlam [1966] \\
\hline Electric Arc & & & Produces Stainless Steel & \\
\hline \multicolumn{5}{|l|}{$\underline{\text { Telecommunications }}$} \\
\hline Telegrams & Mail & time elapsed reduced 3000-fold, cost 100 -fold & & Sichel [1997] \\
\hline Telephone & Telegrams & avg. time spent in three tasks decline by a factor of 3 & & Solymar [1999], Coe [1995], Casson [2004] \\
\hline Mobile Phones & Telephone & increases productivy by one third & & Gallup [1993] \\
\hline \multicolumn{5}{|l|}{ Mass Communication } \\
\hline Newspapers & - & & & \\
\hline Radios & Newspapers & Worse recall rate than Newspapers & Transmits sound & \\
\hline TV's & Radios & Recall rate $30 \%$ better than radio & Transmits image & Hooper [1969], Wells and Hakanen [1997] \\
\hline \multicolumn{5}{|c|}{ Information Technology } \\
\hline PC's & \multicolumn{2}{|c|}{ Typewriters / Calculators / Mainframes } & Fast \& Complex Compu & \\
\hline Robots & Manual Labor & Increase productivity by up to $560 \%$ & Flexible Manufacturing & Ayres and Miller [1983] \\
\hline \multicolumn{5}{|l|}{ Transportation } \\
\hline \multirow[t]{2}{*}{ Railways (Freight) } & Canals/Wagons & With respect to wagons: Speed increases five-fold / Freigh & transported incr. $>100$-fold & Oliver [1956], Locklin [1852] \\
\hline & & With respect to canals: Speed and productivity increase two & or three-fold & Fogel [1964], Stover [1997] \\
\hline Railways (Passangers) & Horse Transportation & Speed increases 10 -fold & & Oliver [1956] \\
\hline Trucks & Railways & Not a substantial increase in speed / modest reduction in c & st in short distances & Warner [1962] \\
\hline Cars & Railways & Not a substantial increase in speed & & Oliver [1956] \\
\hline Planes (Cargo) & Trucks / Railways & Increases speed $<4$-fold, cost increases & & Oliver [1956] \\
\hline Planes (Passangers) & Cars / Railways & Increases speed $<4$-fold, cost increases & & Oliver [1956] \\
\hline Steam and Motor Ships & Sail Ships & 20 percent faster by 1893 & & Oliver [1956] \\
\hline
\end{tabular}

Notes: Shaded Technologies do not have competing predecessors. Freight transportation has a competing predecessor only in those countries where canals were available. 
Table 5: Size of Fixed costs of Predecessor Technology When Predecessor Technology is Competing

\begin{tabular}{|c|c|c|}
\hline New Technology & Previous Technology & Fixed Costs of Predecessor tech. \\
\hline \multicolumn{3}{|l|}{ Textiles } \\
\hline Ring Spindles & Mule Spindles & Small \\
\hline \multicolumn{3}{|l|}{$\underline{\text { Steel }}$} \\
\hline Open Hearth & Bessemer & Large \\
\hline Blast Oxygen & Open Hearth & Large \\
\hline \multicolumn{3}{|l|}{ Telecommunications } \\
\hline Telephone & Telegrams & Large \\
\hline Mobile Phones & Telephone & Large \\
\hline \multicolumn{3}{|l|}{ Mass Communication } \\
\hline Radios & Newspapers & Small \\
\hline TV's & Radios & Small \\
\hline \multicolumn{3}{|l|}{ Transportation } \\
\hline Railways (Freight) & Canals & Large \\
\hline Trucks & Railways & Large \\
\hline Cars & Railways & Large \\
\hline Planes (Cargo) & Trucks / Railways & Large \\
\hline Planes (Passangers) & Cars / Railways & Large \\
\hline Steam and Motor Ships & Sail Ships & Large \\
\hline
\end{tabular}


Table 6: Descriptive Statistics

\begin{tabular}{|c|c|c|c|c|c|}
\hline Variable & Number Obs. & Mean & Std. Dev. & Min & Max \\
\hline Technologies with competing preferences & 2280 & -2.57 & 3.83 & -15.42 & 6.75 \\
\hline Technologies without competing preferences & 1456 & -3.64 & 2.74 & -16.68 & 2.10 \\
\hline Technologies with concentrated, competing predecessor & 1866 & -3.56 & 3.13 & -15.42 & 3.12 \\
\hline Technologies without concentrated, competing predecessor & 1870 & -2.41 & 3.73 & -16.68 & 6.75 \\
\hline Legislative Flexibility & 12581 & 2.38 & 0.94 & 0.00 & 3.00 \\
\hline $\ln (G D P)$ per capita & 9652 & 1.37 & 0.76 & -0.35 & 3.22 \\
\hline Military Regime & 18469 & 0.02 & 0.14 & 0.00 & 1.00 \\
\hline $\ln (\mathrm{MWHR})$ & 5579 & -1.91 & 1.32 & -7.08 & 0.54 \\
\hline Judicial Effect & 16863 & 9.02 & 1.41 & 5.50 & 10.00 \\
\hline Democracy & 10452 & 7.10 & 3.37 & 1.00 & 10.00 \\
\hline $\ln ($ Area $)$ & 18469 & 5.40 & 1.85 & 1.10 & 9.21 \\
\hline $\ln$ (Population) & 8611 & 9.18 & 1.37 & 3.50 & 12.50 \\
\hline $\ln (\mathrm{GDP})$ & 8350 & 10.60 & 1.71 & 3.91 & 15.72 \\
\hline Prim. Enr. before 1970 & 7027 & 0.65 & 0.18 & 0.14 & 1.15 \\
\hline Sec. Enr. before 1970 & 6859 & 0.18 & 0.20 & 0.01 & 1.08 \\
\hline Prim. Enr. after 1970 & 1633 & 1.02 & 0.08 & 0.80 & 1.29 \\
\hline Sec. Enr. After 1970 & 1589 & 0.92 & 0.19 & 0.37 & 1.53 \\
\hline
\end{tabular}


Table 7: Dependent Variable: Technology Diffusion (yict)

\begin{tabular}{|c|c|c|c|c|c|}
\hline Variable & $\mathrm{I}$ & II & III & IV & $\mathrm{V}$ \\
\hline \multicolumn{6}{|l|}{ Controls (Xct) } \\
\hline $\ln (\mathrm{GDP} / \mathrm{Pop})$ & $\begin{array}{c}1.05 \\
(16.12)\end{array}$ & $\begin{array}{c}1.10 \\
(15.26)\end{array}$ & $\begin{array}{c}1.09 \\
(14.69)\end{array}$ & $\begin{array}{c}1.08 \\
(14.60)\end{array}$ & $\begin{array}{c}0.97 \\
(12.20)\end{array}$ \\
\hline Prim. Enr. before 1970 & $\begin{array}{c}1.44 \\
(8.41)\end{array}$ & $\begin{array}{c}1.50 \\
(8.17)\end{array}$ & $\begin{array}{c}1.52 \\
(8.16)\end{array}$ & $\begin{array}{c}1.54 \\
(8.45)\end{array}$ & $\begin{array}{c}1.64 \\
(9.03)\end{array}$ \\
\hline Sec. Enr. before 1970 & $\begin{array}{c}0.11 \\
(0.07)\end{array}$ & $\begin{array}{c}0.18 \\
(1.09)\end{array}$ & $\begin{array}{c}0.20 \\
(1.18)\end{array}$ & $\begin{array}{c}0.20 \\
(1.16)\end{array}$ & $\begin{array}{c}0.10 \\
(0.61)\end{array}$ \\
\hline Prim. Enr. after 1970 & $\begin{array}{c}0.25 \\
(0.47)\end{array}$ & $\begin{array}{c}0.29 \\
(0.49)\end{array}$ & $\begin{array}{c}0.29 \\
(0.49)\end{array}$ & $\begin{array}{c}0.29 \\
(0.49)\end{array}$ & $\begin{array}{c}0.65 \\
(1.08)\end{array}$ \\
\hline Sec. Enr. after 1970 & $\begin{array}{l}-0.41 \\
(-1.48)\end{array}$ & $\begin{array}{l}-0.35 \\
(-1.25)\end{array}$ & $\begin{array}{l}-0.38 \\
(-1.35)\end{array}$ & $\begin{array}{l}-0.37 \\
(-1.32)\end{array}$ & $\begin{array}{l}-0.66 \\
(-2.27)\end{array}$ \\
\hline $\ln ($ electricity production) & $\begin{array}{c}0.22 \\
(8.70)\end{array}$ & $\begin{array}{c}0.20 \\
(8.41)\end{array}$ & $\begin{array}{c}0.21 \\
(8.46)\end{array}$ & $\begin{array}{c}0.21 \\
(8.43)\end{array}$ & $\begin{array}{c}0.17 \\
(6.42)\end{array}$ \\
\hline \multicolumn{6}{|l|}{ Institutions } \\
\hline Democracy & & $\begin{array}{l}-0.08 \\
(-5.12)\end{array}$ & $\begin{array}{l}-0.08 \\
(-5.15)\end{array}$ & $\begin{array}{l}-0.12 \\
(-4.48)\end{array}$ & $\begin{array}{c}-0.11 \\
(-4.19)\end{array}$ \\
\hline Military Regime & & & $\begin{array}{c}0.31 \\
(1.79)\end{array}$ & $\begin{array}{c}0.33 \\
(2.18)\end{array}$ & $\begin{array}{c}0.29 \\
(1.67)\end{array}$ \\
\hline Legislative Flexibility & & & & $\begin{array}{c}0.12 \\
(1.39)\end{array}$ & $\begin{array}{c}0.04 \\
(1.27)\end{array}$ \\
\hline Judicial Effectiveness & & & & & $\begin{array}{c}0.14 \\
(1.45)\end{array}$ \\
\hline \multicolumn{6}{|l|}{ Institut* Incumb. Tech. } \\
\hline Democracy * Incumb. Tech & & $\begin{array}{c}0.11 \\
(8.47)\end{array}$ & $\begin{array}{c}0.10 \\
(8.16)\end{array}$ & $\begin{array}{c}0.16 \\
(5.06)\end{array}$ & $\begin{array}{c}0.13 \\
(3.95)\end{array}$ \\
\hline Mil. Reg. ${ }^{*}$ Incumb. Tech & & & $\begin{array}{c}-0.71 \\
(-2.77)\end{array}$ & $\begin{array}{c}-0.82 \\
(-3.11)\end{array}$ & $\begin{array}{l}-1.00 \\
(-3.43)\end{array}$ \\
\hline Legislat. Flex. * Incumb. Tech & & & & $\begin{array}{c}-0.22 \\
(-2.15)\end{array}$ & $\begin{array}{c}-0.32 \\
(-2.67)\end{array}$ \\
\hline Judicial. Eff. * Incumb. Tech & & & & & $\begin{array}{c}0.07 \\
(2.06)\end{array}$ \\
\hline No. of Obs & 2648 & 2452 & 2452 & 2452 & 2452 \\
\hline $\mathrm{R}^{2}$ (within) & 0.25 & 0.23 & 0.24 & 0.24 & 0.24 \\
\hline
\end{tabular}

Note: t-statistics in parenthesis computed using robust standard errors.

All regressions include a tull set of technology-year tixed etfects. 
Table 8: Dependent Variable: Technology Diffusion (yict)

\begin{tabular}{|c|c|c|c|c|}
\hline Variable & I & II & III & IV \\
\hline \multicolumn{5}{|l|}{ Controls (Xct) } \\
\hline $\ln (\mathrm{GDP} / \mathrm{Pop})$ & $\begin{array}{c}1.10 \\
(15.24)\end{array}$ & $\begin{array}{c}1.09 \\
(14.59)\end{array}$ & $\begin{array}{c}1.08 \\
(14.51)\end{array}$ & $\begin{array}{c}0.97 \\
(12.16)\end{array}$ \\
\hline Prim. Enr. before 1970 & $\begin{array}{c}1.47 \\
(8.03)\end{array}$ & $\begin{array}{c}1.49 \\
(8.11)\end{array}$ & $\begin{array}{c}1.51 \\
(8.30)\end{array}$ & $\begin{array}{c}1.61 \\
(8.93)\end{array}$ \\
\hline Sec. Enr. before 1970 & $\begin{array}{c}0.18 \\
(1.10)\end{array}$ & $\begin{array}{c}0.21 \\
(1.23)\end{array}$ & $\begin{array}{c}0.20 \\
(1.20)\end{array}$ & $\begin{array}{c}0.10 \\
(0.59)\end{array}$ \\
\hline Prim. Enr. after 1970 & $\begin{array}{c}0.25 \\
(0.43)\end{array}$ & $\begin{array}{c}0.23 \\
(0.40)\end{array}$ & $\begin{array}{c}0.22 \\
(0.38)\end{array}$ & $\begin{array}{l}0.57 \\
(0.96)\end{array}$ \\
\hline Sec. Enr. after 1970 & $\begin{array}{l}-0.35 \\
(-1.23)\end{array}$ & $\begin{array}{l}-0.36 \\
(-1.27)\end{array}$ & $\begin{array}{l}-0.36 \\
(-1.26)\end{array}$ & $\begin{array}{l}-0.65 \\
(-2.20)\end{array}$ \\
\hline $\ln ($ electricity production) & $\begin{array}{c}0.21 \\
(8.53)\end{array}$ & $\begin{array}{c}0.21 \\
(8.56)\end{array}$ & $\begin{array}{c}0.21 \\
(8.56)\end{array}$ & $\begin{array}{c}0.17 \\
(6.44)\end{array}$ \\
\hline \multicolumn{5}{|l|}{ Institutions } \\
\hline Democracy & $\begin{array}{l}-0.07 \\
(-4.53)\end{array}$ & $\begin{array}{l}-0.07 \\
(-4.57)\end{array}$ & $\begin{array}{l}-0.10 \\
(-4.68)\end{array}$ & $\begin{array}{l}-0.10 \\
(-4.40)\end{array}$ \\
\hline Military Regime & & $\begin{array}{c}0.12 \\
(0.76)\end{array}$ & $\begin{array}{c}0.18 \\
(1.26)\end{array}$ & $\begin{array}{c}0.16 \\
(1.00)\end{array}$ \\
\hline Legislative Flexibility & & & $\begin{array}{c}0.12 \\
(1.71)\end{array}$ & $\begin{array}{c}0.14 \\
(1.79)\end{array}$ \\
\hline Judicial Effectiveness & & & & $\begin{array}{c}0.05 \\
(1.84)\end{array}$ \\
\hline$\frac{\text { Institut } * \text { Concen. Pred. }}{\text { Democracy * Concen. Pred. }}$ & $\begin{array}{c}0.10 \\
(7.79)\end{array}$ & $\begin{array}{c}0.10 \\
(7.44)\end{array}$ & $\begin{array}{c}0.15 \\
(5.22)\end{array}$ & $\begin{array}{c}0.12 \\
(3.86)\end{array}$ \\
\hline Mil. Reg. * Concen. Pred. & & $\begin{array}{c}-0.51 \\
(-1.83)\end{array}$ & $\begin{array}{c}-0.64 \\
(-2.30)\end{array}$ & $\begin{array}{c}-0.88 \\
(-2.97)\end{array}$ \\
\hline Legislat. Flex. * Concen. Pred. & & & $\begin{array}{c}-0.22 \\
(-2.36)\end{array}$ & $\begin{array}{c}-0.35 \\
(-3.14)\end{array}$ \\
\hline Judicial. Eff. * Concen. Pred. & & & & $\begin{array}{c}0.08 \\
(2.71)\end{array}$ \\
\hline No. of Obs & 2452 & 2452 & 2452 & 2452 \\
\hline $\mathrm{R}^{2}$ (within) & 0.23 & 0.23 & 0.23 & 0.24 \\
\hline
\end{tabular}

Note: t-statistics in parenthesis computed using robust standard errors.

All regressions include a full set of technology-year fixed effects. 
Table 9: Dependent Variable: Technology Diffusion (yict)

\begin{tabular}{|c|c|c|c|c|c|c|c|c|}
\hline Variable & $\mathrm{I}$ & II & III & IV & $\mathrm{V}$ & $\mathrm{VI}$ & VII & VIII \\
\hline \multicolumn{9}{|l|}{ Lagged Institut * Incumb. Tech. } \\
\hline Lagged Democracy * Incumb. Tech. & $\begin{array}{c}0.13 \\
(4.29)\end{array}$ & & $\begin{array}{c}0.13 \\
(2.37)\end{array}$ & & $\begin{array}{c}0.13 \\
(2.71)\end{array}$ & & $\begin{array}{c}0.07 \\
(7.83)\end{array}$ & \\
\hline Lagged Mil. Reg. * Incumb. Tech. & $\begin{array}{l}-1.19 \\
(-4.16)\end{array}$ & & $\begin{array}{l}-1.19 \\
(-3.55)\end{array}$ & & $\begin{array}{l}-1.19 \\
(-2.80)\end{array}$ & & $\begin{array}{c}-0.45 \\
(-5.58)\end{array}$ & \\
\hline Lagged Legislat. Flex. * Incumb. Tech. & $\begin{array}{l}-0.35 \\
(-3.01)\end{array}$ & & $\begin{array}{c}-0.35 \\
(-1.95)\end{array}$ & & $\begin{array}{c}-0.35 \\
(-1.96)\end{array}$ & & $\begin{array}{l}-0.11 \\
(-3.20)\end{array}$ & \\
\hline $\begin{array}{l}\text { Lagged Judicial. Eff. * Incumb. Tech. } \\
\text { Lagged Institut * Concen. Pred. }\end{array}$ & $\begin{array}{c}0.09 \\
(2.93)\end{array}$ & & $\begin{array}{c}0.09 \\
(1.44)\end{array}$ & & $\begin{array}{c}0.09 \\
(1.63)\end{array}$ & & $\begin{array}{c}0.06 \\
(5.16)\end{array}$ & \\
\hline Lagged Democracy * Concen. Pred. & & $\begin{array}{c}0.13 \\
(4.52)\end{array}$ & & $\begin{array}{c}0.13 \\
(2.41)\end{array}$ & & $\begin{array}{c}0.13 \\
(2.90)\end{array}$ & & $\begin{array}{c}0.07 \\
(6.54)\end{array}$ \\
\hline Lagged Mil. Reg. * Concen. Pred. & & $\begin{array}{l}-1.09 \\
(-3.72)\end{array}$ & & $\begin{array}{l}-1.09 \\
(-2.72)\end{array}$ & & $\begin{array}{l}-1.09 \\
(-2.51)\end{array}$ & & $\begin{array}{l}-0.40 \\
(-5.16)\end{array}$ \\
\hline Lagged Legislat. Flex. * Concen. Pred. & & $\begin{array}{l}-0.40 \\
(-3.63)\end{array}$ & & $\begin{array}{l}-0.40 \\
(-2.49)\end{array}$ & & $\begin{array}{l}-0.40 \\
(-2.55)\end{array}$ & & $\begin{array}{c}-0.11 \\
(-3.21)\end{array}$ \\
\hline Lagged Judicial. Eff. * Concen. Pred. & & $\begin{array}{c}0.09 \\
(3.25)\end{array}$ & & $\begin{array}{c}0.09 \\
(1.48)\end{array}$ & & $\begin{array}{c}0.09 \\
(1.87)\end{array}$ & & $\begin{array}{c}0.07 \\
(6.11)\end{array}$ \\
\hline $\begin{array}{l}\text { Error Term } \\
\text { Cluster }\end{array}$ & No & No & Country & Country & Tech-Coun & Tech-Coun & Tech-Coun & Tech-Cour \\
\hline Serial Correlation & No & No & No & No & No & No & Yes & Yes \\
\hline No. of obs & 2427 & 2427 & 2427 & 2427 & 2427 & 2427 & 2411 & 2411 \\
\hline $\mathrm{R}^{2}$ (within) & 0.24 & 0.24 & 0.24 & 0.24 & 0.24 & 0.24 & - & - \\
\hline
\end{tabular}

Note: t-statistics computed using robust standad errors in parenthesis. All regressions control for income per capita,

enrollment in primary and secondary education and electricity production. All regressions include a full set of technology-country fixed effects.

Columns III and IV cluster the error terms at the country level. Columns V and VI cluster the error terms at the technology-country level.

Columns VII and VIII allow for heteroskedastic errors with a different AR(1) process for the errors terms in each technology-country cluster. 


\section{Table 10: Robustness: Technology Diffusion with and without Incumbent Technologies}

Variable

I

II

III

IV

$\mathrm{V}$

VI

VII

VIII

Controls * Incumb. Tech.

$\ln$ (GDP/Pop) * Incumb. Tech

0.24

Prim. Enr. 70-* Incumb. Tech

0.15

Sec. Enr. 70-* Incumb. Tech

1.36

Prim. Enr. 70+* Incumb. Tech

$-0.58$

Sec. Enr. 70+* Incumb. Tech

0.88

$\ln (\text { electricity })^{*}$ Incumb. Tech

0.03

(0.56)

$\ln ($ Area $) *$ Incumb. Tech

0.14

(3.79)

$\ln$ (Population) * Incumb. Tech

$-0.13$

$(-3.44)$

$\ln (\mathrm{GDP}) *$ Incumb. Tech

$-0.04$

$(-1.22)$

Institut* Incumb. Tech.

Lagged Democracy * Incumb. Tech

$$
0.13
$$

0.15

0.11

0.10

$$
0.15
$$

0.13

0.11

0.05

Lagged Legislat. Flex. * Incumb. Tech

$-0.35 \quad-0.64$

(3.58)

(2.57)

(3.84)

(4.10)

(3.44)

(1.27)

$-0.31$

$-0.41$

$-0.51$

$-0.40$

$-0.27$

$-0.36$

$(-2.33)$

$(-2.31)$

$(-2.88)$

$(-3.41)$

$(-2.03)$

Lagged Mil. Reg. * Incumb. Tech

$$
-1.19
$$

$-1.48$

$-1.13$

$-1.49$

$-1.58$

$-1.14$

$-0.89$

$-0.49$

$(-4.16)$

$(-3.50)$

$(-3.88)$

$(-4.17)$

$(-3.86)$

$(-2.69)$

Lagged Judicial. Eff. * Incumb. Tech

$\begin{array}{lll}0.09 & 0.16 & 0.02\end{array}$

0.15

0.14

0.09

0.04

(0.43)

(4.35)

(3.93)

(3.14)

(1.07)

Dummies

Country Dummies

\begin{tabular}{llllllll} 
No & No & No & No & No & Yes & No & Yes \\
No & No & No & No & No & No & Yes & Yes \\
No & Yes & No & No & No & No & No & No \\
2427 & 2427 & 2427 & 2210 & 2210 & 2427 & 2427 & 2427 \\
0.24 & 0.26 & 0.25 & 0.21 & 0.19 & 0.28 & 0.28 & 0.32 \\
\hline
\end{tabular}

Note: t-statistics computed using robust standad errors in parenthesis. All regressions include a full set of technology-country fixed effects. All regressions control for income per capita, enrollment in primary and secondary education and electricity production. Regression III controls in addition for $\ln ($ area) and for $\ln$ (population). Regression IV controls in addition for $\ln (\mathrm{GDP})$. 
Table 11: Robustness: Technology Diffusion with and without Competing and Concentrated Predecessors

\begin{tabular}{|c|c|c|c|c|c|c|c|c|}
\hline Variable & $\mathrm{I}$ & II & III & IV & $\mathrm{V}$ & VI & VII & VIII \\
\hline \multicolumn{9}{|l|}{ Controls * Concen. Pred. } \\
\hline $\ln (\mathrm{GDP} / \mathrm{Pop}) *$ Concen. Pred & & & $\begin{array}{c}0.15 \\
(1.00)\end{array}$ & & & & & \\
\hline Prim. Enr. 70-* Concen. Pred & & & $\begin{array}{c}0.60 \\
(1.73)\end{array}$ & & & & & \\
\hline Sec. Enr. 70-* Concen. Pred & & & $\begin{array}{c}0.51 \\
(1.54)\end{array}$ & & & & & \\
\hline Prim. Enr. $70+*$ Concen. Pred & & & $\begin{array}{c}0.08 \\
(0.07)\end{array}$ & & & & & \\
\hline Sec. Enr. $70+*$ Concen. Pred & & & $\begin{array}{c}0.13 \\
(0.21)\end{array}$ & & & & & \\
\hline $\ln (\text { electricity })^{*}$ Concen. Pred & & & $\begin{array}{c}0.03 \\
(0.69)\end{array}$ & & & & & \\
\hline $\ln ($ Area $) *$ Concen. Pred & & & & $\begin{array}{c}0.14 \\
(4.95)\end{array}$ & & & & \\
\hline $\ln$ (Population) $*$ Concen. Pred & & & & $\begin{array}{c}-0.16 \\
(-5.12)\end{array}$ & & & & \\
\hline $\ln (\mathrm{GDP}) *$ Concen. Pred & & & & & $\begin{array}{c}-0.06 \\
(-2.42)\end{array}$ & & & \\
\hline \multicolumn{9}{|l|}{ Institut* Concen. Pred. } \\
\hline Lagged Democracy $*$ Concen. Pred & $\begin{array}{c}0.13 \\
(4.52)\end{array}$ & $\begin{array}{c}0.15 \\
(4.63)\end{array}$ & $\begin{array}{c}0.11 \\
(3.65)\end{array}$ & $\begin{array}{c}0.10 \\
(2.66)\end{array}$ & $\begin{array}{c}0.15 \\
(4.03)\end{array}$ & $\begin{array}{c}0.12 \\
(4.23)\end{array}$ & $\begin{array}{c}0.10 \\
(3.40)\end{array}$ & $\begin{array}{c}0.06 \\
(1.77)\end{array}$ \\
\hline Lagged Legislat. Flex. $*$ Concen. Pred & $\begin{array}{c}-0.40 \\
(-3.63)\end{array}$ & $\begin{array}{c}-0.64 \\
(-4.28)\end{array}$ & $\begin{array}{c}-0.43 \\
(-3.42)\end{array}$ & $\begin{array}{c}-0.31 \\
(-1.96)\end{array}$ & $\begin{array}{c}-0.42 \\
(-2.61)\end{array}$ & $\begin{array}{c}-0.43 \\
(-3.90)\end{array}$ & $\begin{array}{c}-0.37 \\
(-2.92)\end{array}$ & $\begin{array}{c}-0.38 \\
(-2.94)\end{array}$ \\
\hline Lagged Mil. Reg. * Concen. Pred & $\begin{array}{l}-1.09 \\
(-3.72)\end{array}$ & $\begin{array}{c}-1.48 \\
(-5.04)\end{array}$ & $\begin{array}{c}-1.06 \\
(-3.30)\end{array}$ & $\begin{array}{l}-1.36 \\
(-3.44)\end{array}$ & $\begin{array}{c}-1.47 \\
(-3.74)\end{array}$ & $\begin{array}{c}-1.11 \\
(-3.72)\end{array}$ & $\begin{array}{c}-0.83 \\
(-2.41)\end{array}$ & $\begin{array}{c}-0.62 \\
(-1.81)\end{array}$ \\
\hline Lagged Judicial. Eff. * Concen. Pred & $\begin{array}{c}0.09 \\
(3.25)\end{array}$ & $\begin{array}{c}0.15 \\
(4.23)\end{array}$ & $\begin{array}{c}0.05 \\
(1.37)\end{array}$ & $\begin{array}{c}0.15 \\
(4.81)\end{array}$ & $\begin{array}{c}0.14 \\
(4.34)\end{array}$ & $\begin{array}{c}0.10 \\
(3.48)\end{array}$ & $\begin{array}{c}0.07 \\
(1.74)\end{array}$ & - \\
\hline \multicolumn{9}{|l|}{ Dummies } \\
\hline Country Dummies & No & No & No & No & No & Yes & No & Yes \\
\hline Country Dummies * Concen. Pred. & No & No & No & No & No & No & Yes & Yes \\
\hline Sector Dummies*Institutional Var. & No & Yes & No & No & No & No & No & No \\
\hline No. of obs & 2427 & 2427 & 2427 & 2210 & 2210 & 2427 & 2427 & 2427 \\
\hline $\mathrm{R}^{2}$ (within) & 0.24 & 0.26 & 0.25 & 0.22 & 0.20 & 0.28 & 0.28 & 0.31 \\
\hline
\end{tabular}

Note: t-statistics computed using robust standad errors in parenthesis. All regressions include a full set of technology-country fixed effects. All regressions control for income per capita, enrollment in primary and secondary education and electricity production.

Regression III controls in addition for $\ln$ (area) and for $\ln$ (population). Regression IV controls in addition for $\ln (\mathrm{GDP})$. 
Table A1: The Cost of Constructing Canals

\begin{tabular}{lcccc}
\hline \hline Name & Country & Cost & Length & Construction Period \\
\hline & & & & \\
Erie & US & 7 Mill. $\$$ & $584 \mathrm{Km}$ & $1817-25$ \\
Chesapeake and Delaware & US & $2.5 \mathrm{Mill} \$$ & $22.4 \mathrm{Km}$ & $1804-28$ \\
Rideau & Canada & $£ 822,000$ & $200 \mathrm{Km}$ & $1812-32$ \\
Regent & UK & $£, 772,000$ & $182 \mathrm{Km}$ & $1812-20$ \\
Rhone-Rhine & France & 28 Mill. F.F. & $350 \mathrm{Km}$ & -1834 \\
Somme & France & 13 Mill. F.F. & $161 \mathrm{Km}$ & $1770-1843$ \\
Ardennes & France & 14 Mill. F.F. & $105 \mathrm{Km}$ & $1823-31$ \\
Oise River & France & 5 Mill. F.F. & $138 \mathrm{Km}$ & -1810 \\
Isle River & France & 6 Mill. F.F. & $143 \mathrm{Km}$ & \\
Burgundy & France & 56 Mill. F.F. & $242 \mathrm{Km}$ & -1832 \\
Arles-Bouc & France & $11.5 \mathrm{Mill}$. F.F. & $47 \mathrm{Km}$ & -1834 \\
Brittany & France & 66 Mill. F.F. & $518 \mathrm{Km}$ & -1836 \\
Nivernais & France & 33 Mill. F.F. & $174 \mathrm{Km}$ & $1784-1843$ \\
Berri & France & 27 Mill. F.F. & $322 \mathrm{Km}$ & $1811-34$ \\
Loire lateral & France & 33 Mill. F.F. & $197 \mathrm{Km}$ & $1827-38$ \\
Tarn River & France & 7 Mill. F.F. & $147 \mathrm{Km}$ & $1667-94$ \\
& & & \\
\hline \hline
\end{tabular}

Note: Cost expressed in current prices at the time of construction. 


\begin{tabular}{|c|c|c|c|c|}
\hline Variable & $\mathrm{I}$ & II & III & IV \\
\hline \multicolumn{5}{|l|}{ Institutions } \\
\hline$\overline{\text { Democracy }}$ & $\begin{array}{l}-0.11 \\
(-4.19)\end{array}$ & $\begin{array}{l}-0.12 \\
(-4.79)\end{array}$ & $\begin{array}{l}-0.10 \\
(-4.40)\end{array}$ & $\begin{array}{l}-0.11 \\
(-4.98)\end{array}$ \\
\hline Military Regime & $\begin{array}{c}0.29 \\
(1.67)\end{array}$ & $\begin{array}{c}0.23 \\
(1.34)\end{array}$ & $\begin{array}{c}0.16 \\
(1.00)\end{array}$ & $\begin{array}{c}0.17 \\
(1.08)\end{array}$ \\
\hline Legislative Flexibility & $\begin{array}{c}0.04 \\
(1.27)\end{array}$ & $\begin{array}{l}0.12 \\
(1.2)\end{array}$ & $\begin{array}{c}0.14 \\
(1.79)\end{array}$ & $\begin{array}{c}0.13 \\
(1.76)\end{array}$ \\
\hline Judicial Effectiveness & $\begin{array}{c}0.14 \\
(1.45)\end{array}$ & $\begin{array}{l}0.05 \\
(1.6)\end{array}$ & $\begin{array}{c}0.05 \\
(1.84)\end{array}$ & $\begin{array}{l}0.05 \\
(1.8)\end{array}$ \\
\hline \multicolumn{5}{|l|}{ Institut $^{*}$ Technology Classification } \\
\hline Democracy $*$ Technology Classification & $\begin{array}{l}0.13 \\
(3.95)\end{array}$ & $\begin{array}{c}0.14 \\
(4.27)\end{array}$ & $\begin{array}{c}0.12 \\
(3.86)\end{array}$ & $\begin{array}{c}0.13 \\
(4.05)\end{array}$ \\
\hline Mil. Reg. * Technology Classification & $\begin{array}{l}-1.00 \\
(-3.43)\end{array}$ & $\begin{array}{l}-0.89 \\
(-2.98)\end{array}$ & $\begin{array}{l}-0.88 \\
(-2.97)\end{array}$ & $\begin{array}{l}-0.89 \\
(-2.94)\end{array}$ \\
\hline Legislat. Flex. * Technology Classification & $\begin{array}{l}-0.32 \\
(-2.67)\end{array}$ & $\begin{array}{l}-0.30 \\
(-2.52)\end{array}$ & $\begin{array}{l}-0.35 \\
(-3.14)\end{array}$ & $\begin{array}{l}-0.37 \\
(-3.37)\end{array}$ \\
\hline Judicial. Eff. * Technology Classification & $\begin{array}{c}0.07 \\
(2.06)\end{array}$ & $\begin{array}{c}0.06 \\
(1.86)\end{array}$ & $\begin{array}{l}0.08 \\
(2.71)\end{array}$ & $\begin{array}{c}0.10 \\
(3.21)\end{array}$ \\
\hline $\begin{array}{l}\text { Technology Classification } \\
\text { Technology Measure }\end{array}$ & $\begin{array}{l}\text { Inc. Tech. } \\
\text { Baseline }\end{array}$ & $\begin{array}{l}\text { Inc. Tech. } \\
\text { Per capita }\end{array}$ & $\begin{array}{l}\text { Concen. Pred. } \\
\text { Baseline }\end{array}$ & $\begin{array}{l}\text { Concen. Pred } \\
\text { Per capita }\end{array}$ \\
\hline No. of Obs & 2452 & 2452 & 2452 & 2452 \\
\hline $\mathrm{R}^{2}$ (within) & 0.24 & 0.3 & 0.24 & 0.31 \\
\hline
\end{tabular}

Note: t-statistics in parenthesis computed using robust standard errors.

All regressions include a full set of technology-year fixed effects and the usual controls in Xct: income per capita, enrollment rates and electricity production.

Inc. Tech. denotes the classification based on whether the technology has a close predecessor technology. Concen. Predec. Denotes the classification based on whether the technology has a close and concentrated predecessor technology. 